\title{
Key Factors Influencing Low-Carbon Behaviors of Staff in Star-Rated Hotels-An Empirical Study of Eastern China
}

\author{
Jie Li $\left.{ }^{1}{ }^{(}\right)$, Peng Mao ${ }^{2} \mathbb{D}$, Hui Liu ${ }^{2}$, Jiawei Wei ${ }^{3}$, Hongyang Li $^{4, *}$ and Jingfeng Yuan ${ }^{5}$ \\ 1 School of Civil and Transportation Engineering, Shenzhen University, Shenzhen 518060, China; \\ lijie20181@email.szu.edu.cn \\ 2 College of Civil Engineering, Nanjing Forestry University, Nanjing 210037, China; \\ maopeng@njfu.edu.cn (P.M.); liuhui@njfu.edu.cn (H.L.) \\ 3 Research Institute of Zhongjiao Sihang, Guangzhou 510220, China; wjiawei1@ccc4.com \\ 4 Business School, Hohai University, Nanjing 211100, China \\ 5 School of Civil Engineering, Southeast University, Nanjing 210096, China; jingfeng-yuan@seu.edu.cn \\ * Correspondence: lihy@hhu.edu.cn
}

Received: 31 August 2020; Accepted: 2 November 2020; Published: 6 November 2020

\begin{abstract}
To guide sustainable development in the hospitality industry requires hotel staff engagement, so what causes and how to facilitate the implementation of low-carbon behaviors should be high priorities. However, most prior studies focused on hotel guest behavior or discussed, on an individual level, the psychological aspects of the factors of the low-carbon behavior of either managers or employees. Therefore, this research aims to examine the effect of influencing factors inside and outside of the hotel context on hotel staff's low-carbon behaviors in star-rated hotels. A set of influencing factors were identified by using literature retrieval, ground theory and in-depth interviews. Structural equation modelling was then applied with 440 valid questionnaires collected from representative star-rated hotels in Eastern China. The results revealed that low-carbon managerial activities, strategic orientation, social norms, and perceived behavior control were four key factors affecting the low-carbon behavior adoption of staff from star-rated hotels. Among them, low-carbon managerial activities were found to be the strongest factor affecting hotel staff's low-carbon behaviors. Consumer attitude, however, exerted no significant impact. Targeted strategies were finally proposed for the improvement of hotel staff's low-carbon behavior from the perspectives of hoteliers and governments. This study contributes to the generation mechanism of low-carbon behavior among staff and, in practice, towards behavioral improvement by providing comprehensive insights about the attribution of factors belonging to multiple dimensions related to the low-carbon behavior of staff in the hotel industry.
\end{abstract}

Keywords: low-carbon behaviors; hotel staff; influencing factors; star-rated hotels; targeted strategies

\section{Introduction}

Global warming opens Pandora's box-with adverse impacts on the environment, aggravated by human behaviors, without effective intervention. The lodging industry, involving various anthropogenic activities, poses great environmental pressure to ecosystems [1]. Hotels, as the primary units of accommodation, have witnessed an imposing growth in tourism in recent years. However, they have also become major energy-intensive end users in many countries due to the heavy dependence on the supply of energy, accounting for a significant proportion (around 20\%) of carbon dioxide emissions in the tourism sector on a global scale [2,3]. Meanwhile, the domestic situation regarding this is equally dire in China. Statistically, hotels were the second highest energy-consuming buildings in Beijing, the capital of China, after shopping malls, among commercial buildings [4]. A similar situation was 
reported in the research of Xing et al., 2015 [5] in which hotel buildings consumed higher energy than any other types of non-residential buildings in Tianjin, China. Nowadays, hotels in China suffer the problems of a high cost input, high energy consumption, and high environmental pollution (so-called $3 \mathrm{H}$ problems) during their daily operations due to $24 / 7$ arrangements, superior facilities/functions, and a free reign on energy use in guests' rooms [6]. In particular, many sizable star-rated hotels providing higher-level living comfort and service quality result in more energy/water use and larger amounts of greenhouse gas emissions. They are thus chief contributors to environmental issues in the lodging industry [6,7]. In this context, star-rated hotels face an imperative shift towards low-carbon development. It is therefore significant to promote effective low-carbon practice in star-rated hotels.

Over the last few years, the hotel sector in China has started to implement a wide spectrum of low-carbon practices to comply with sustainable demand across the whole of society, such as sustainable management regulations, recycling products/facilities, and green training [8-10]. Nevertheless, the situation of $\mathrm{CO}_{2}$ emissions in hotels seems not to have been mitigated much and, instead, an average annual increase of $3.2 \%$ in China was witnessed [11]. Hotel staff, as major actors who provide accommodation services, are endeavoring to solve such issues. Particularly, the low-carbon strategies are proposed by those at the top management level, aiming to meet industrial or societal expectations and, accordingly, internal employees' low-carbon engagement needs to remain consistent with their organizations [12]. It seems that they have more control than outside guests over the low-carbon performance of hotels through their own behavior change. However, some hotel staff, either hoteliers or employees, exhibited non-low-carbon behaviors in practice [13]. Therefore, it is especially important to research the factors underlying hotel staff's low-carbon behaviors so as to enable their effective low-carbon work engagement in star-rated hotels.

The previous literature regarding low-carbon behavior in the hospitality industry mainly focused on the guest side, including drivers of guests' intentions to behave pro-environmentally or guest loyalty in relation to visiting green hotels, guest perception of low-carbon practice in hotels, and so forth $[2,14]$. Compared with this, the factors that influence hotel staff's low-carbon behaviors in the workplace have been relatively neglected [12]. Although there are existing empirical studies on what causes the pro-environmental behavior of hotel employees, the majority discussed these causes on individual levels, such as environmental beliefs, personal attitudes, intrinsic motivations, environmental knowledge, environmental awareness, environmental concern, work engagement, etc. [15-18]. There is still a relative paucity of research on the factors influencing hotel staff's low-carbon behaviors by taking into consideration the multiple dimensions inside and outside of the hotel context, leading to limited contributions to the theoretical mechanisms of factor effects on staff's low-carbon behaviors, as well as to practical guidance for star-rated hotels becoming more green.

Based on such a research gap, this research aims to identify the key influencing factors of staff's low-carbon behaviors in star-rated hotels in the context of Eastern China. Three specific sub-motivations are proposed: (1) What are the key factors affecting staff's low-carbon behavior implementation? (2) How do the identified factors affect staff's low-carbon behaviors in star-rated hotels differently? (3) What strategies could be proposed to improve staff's low-carbon behaviors in order to boost star-rated hotels' efforts to become much greener? The findings from this research will contribute to compensating for the limitation of studying influencing factors on staff's low-carbon behaviors in star-rated hotels from both inside and outside of the hotel context, deepening our understanding of behavior generation mechanisms in the lodging industry. Moreover, this study provides valuable implications for how to guide hotel staff towards low-carbon behaviors by incorporating key influencing factors into effective strategies for hoteliers and the authorities, which assist star-rated hotels in China to achieve environmentally friendly industrial development in order to contribute to the long-term sustainability of society. 


\section{Literature Review}

\subsection{Previous Research on Hotel Low-Carbon Behavior}

Low-carbon behaviors were defined by Stern (2000) as behaviors affecting the utility of substances or energy positively, and those able to alter the structure and dynamics of an ecosystem/biosphere positively [19]. Hence, the deep retrieval of hotel actions, such as "low carbon practice", "sustainable management", "corporate sustainability", etc., is needed when it comes to low-carbon behavior in the lodging industry. Some scholars highlighted how a hotel sector put low carbon into practice from the perspective of eco-technology adoption, including integrated $\mathrm{CO}_{2}$ systems, renewable energy alternatives, HVAC (Heating, Ventilation and Air Conditioning) system renovation, etc. [20-22]. Nevertheless, the environmental performance of hotels, as a typical, traditional service, seems more sensitive in contrast to how hotel stakeholders behave. To date, existing studies have focused primarily on consumer behavior in hotels and presented different antecedents of consumer behavioral intentions towards green hotel visits, willingness to pay, check-in satisfaction and loyalty, or the reuse activities of hotel products $[2,17,23-25]$.

Furthermore, there has been an intensification of concern for environmental protection and green practice in hotels, with increasing studies providing insights about the operator experience in the hospitality industry. For instance, Stefanica et al., (2020) identified that the ecological purchase behaviors of hotel managers were positively influenced by environmental attitudes and economic benefits in an investigation covering 92 hotels in Romania [26]. Volpi and Paulino (2018) argued that the importance of the lodging service that hotels provided could not be denied regarding the environmental requirements of sustainable tourism; however, in their research, the statistics were only partially related to the environmental performance of the sector [27]. Moreover, Mar and Rodríguez (2011) conducted an empirical analysis to highlight the roles of certified management systems in the hotel business and found organizational behavior differences between the implementation of management systems in the Spanish hospitality industry [28]. Nonetheless, most relevant studies partly considered how hotels implemented low-carbon practice on one single level of operation. Although some research papers concluded that both the sustainable strategies of top-level management and the organizational work practices of lower managers and front-line employees were integral parts of corporate sustainability in the hotel industry [29], they were merely concerned about behavior translation modes, without exploring the underlying determinants of different staff behaviors. This research is thus targeted at identifying which key factors trigger low-carbon behaviors, embodying how staff at different levels act in an eco-friendly manner in the lodging industry.

The current literature shows no evidence that there is a unified definition of the low-carbon behavior of staff in hotels, but scholars have researched different aspects that they believe to be of relevance from their own points of view. For instance, Ann and Pearce (2013) used the case study method to identify and discuss low-carbon design strategies in two luxury hotels in America [30]. Hsu et al., (2014) established an evaluation model of suppliers' carbon and energy management performance to research how to select low-carbon suppliers based on the hotel industry [31]. Liu and Pan (2016) pointed out that hotel employees should try their best to minimize the use of facilities that consume a lot of power and encourage guests to reduce the use of disposable cleaning products [32]. As low-carbon behavior belongs to pro-environmental behavior in the domain of environmental sociology and it derives from corporate social responsibility, which shows the voluntary corporate commitment to promoting social and environmental goals when it comes to an enterprise's pro-environmental behavior [33], this paper defined the low-carbon behavior of staff in star-rated hotels as daily anthropogenic activities in relation to hotel staff at different levels, from upper management to middle- and lower-level employees. Their behaviors were grouped into five categories according to the literature retrieval results and hotel sector functions, as shown in Table 1. 
Table 1. Low-carbon behaviors of staff in star-rated hotels.

\begin{tabular}{cc}
\hline Category & Behavior \\
\hline & low-carbon design behavior \\
low-carbon behaviors & low-carbon procurement behavior \\
of hotel staff & low-carbon decision-making behavior \\
& low-carbon operation behavior \\
& low-carbon execution behavior \\
\hline
\end{tabular}

\subsection{Previous Research on Factors Influencing Low-Carbon Behavior in Hotels}

In the current literature, there exist many different studies exploring factors affecting low-carbon behaviors in the hospitality industry. Verma and Chandra (2018) extended the model of the theory of planned behavior, including reflectiveness and conscientiousness, to predict young Indian consumers' green hotel visit intentions [34]. Chuah et al., (2020) explained the psychological mechanisms and boundary conditions of how perceived corporate social responsibility-brand fit affected sustainable customer engagement behavior [26]. Merli et al., (2019) tested the relationship between guest perceived hotel green practice performance and their behavioral intentions in ecolabel-awarded hotels, concluding that staying at green hotels leads guests to develop loyalty toward them [2]. Moreover, research by Gössling et al., (2019) showed that various factors influenced the pro-environmental behavior of hotel tourists, such as nationality, age, length of stay, and comprehensive message designs [35]. However, these scholars paid more attention to what triggered the low-carbon behavior of hotel guests rather than on the hotel service side of the hospitality industry. Thus, there is still sufficiently large scope to research the influencing factors of hotel staff's low-carbon behavior.

The environmental behavior of guests, on the one hand, and low-carbon hotel marketing, on the other hand, have both urged the accommodation sector to reconcile the conventional conflicts between economic benefits and environmental quality [36]. Hence, researchers have also been building upon the view of hotel service and their concerns about the guest perception of hotels' low-carbon practice has recently grown $[37,38]$. However, they mainly explored how contributors affected low-carbon behaviors in hotels from individual guests' experiences. Additionally, Fatoki (2019) pointed out that leadership mechanisms and workplace support could nurture hotel employees' pro-environmental behaviors [12]. Molina et al. (2015) deemed that that the ability of employees to utilize their knowledge or skills in low-carbon practice reflected the capability of green quality management in the hotel industry [39]. Wong and Kim (2020) confirmed that hotels' corporate social responsibility, as perceived by internal staff, made a difference to sustainability and responsible management in the lodging industry [40]. In another piece of research by Osman et al., (2020), they investigated the impact of job insecurity and work engagement on hotel employees' non-green behaviors and found that job insecurity eroded work engagement and exacerbated non-green behaviors [18]. Nonetheless, the above relevant studies were conducted on individual levels, mostly in relation to psychological aspects, in explorations of the factors influencing the low-carbon behavior of either managers or employees in hotels.

There are some other studies discussing non-staff related factors. Dube and Nhamo (2020) pointed that policy elements like municipal bylaws could guide the ideals of green and sustainable development for hotel construction activities [41]. Similarly, Mohammad et al., (2021) believed that policymakers, as key stakeholders, should make an attempt at adjusting punitive economic sanctions in time to provide hoteliers with access to the latest modern energy conservation technologies [42]. Design issues are regarded as among the mitigating factors that influence hotel staff to adopt low-carbon behavior. For instance, the architectural design of thatching may make it difficult to install renewable energy products in the operation stage of the hospitality sector [42]. Overall, empirical studies provide a holistic view of the factors inside and outside of hotels that affect low-carbon behavior among staff in the lodging industry and show that research in this area is still limited. 


\section{Factor Identification and Hypotheses Development}

\subsection{Literature Retrieval Process}

Retrieving the existing studies is a key step for factor identification. In order to systematically and precisely collect the variables, inducing low-carbon behavior among staff in star-rated hotels, Web of Science (WoS) was primarily chosen for literature retrieval as it was judged to be one of the most comprehensive and dependable sources, covering not only the domains of natural science and engineering, but also social science, arts and humanities [43,44]. An advanced search provided by the WoS core collection database was conducted with the following retrieval codes: $\mathrm{TS}=\left(\left(\right.\right.$ hotel $^{*} \mathrm{OR}$ lodging* OR hospitality) AND ((green OR low-carbon OR low carbon OR sustainabl*) AND (behavio* OR practic ${ }^{*}$ OR manag* OR operat*))). In total, 1923 relevant articles published in English since 2010 were initially retrieved from WoS. These papers were further filtered according to research orientations and the top 50\% of cited journals in the database. Other well-known databases, including ScienceDirect, Google Scholar and Scopus were then searched to update and supplement the search results. Finally, 657 directly related articles were critically reviewed from Sustainability (99), International Journal of Contemporary Hospitality Management (84), International Journal of Hospitality Management (82), Journal of Sustainable Tourism (65), Journal of Cleaner Production (36), and Tourism Management (35), to name but a few.

\subsection{Theoretical Background}

Behavior tends to be triggered by certain stimuli, also called drivers of behavior [45], so it is critical to understand what induces low-carbon behavior among staff in star-rated hotels. There are many explorations on the influencing factors of people's low-carbon behaviors, and such studies mainly used the theory of planned behavior (TPB) to illustrate the relationship between the subjects' behaviors and psychology-related factors [34,46]. However, the explored TPB model did not include all triggers relevant to pro-environmental behavior, only those on an individual level. When it comes to corporate behavior, which is always dominated by top-level management, especially in energy-intensive industries like tourism, hospitality and transport, many concerns are increasingly being raised on the altruistic effort that corporates make towards social and environmental benefits, and these studies mostly come from the theory of corporate social responsibility (TCSR) [47,48]. Concerning that the studied hotel staff include both top management and front-line employees, TPB and TCSR are merged in this research. Moreover, there is a general consensus that social context strongly affects people's actions $[49,50]$. Particularly in classical problems of social theory, those regarding behaviors influenced by social relationships or stakeholder interactions, are trying to be solved by researchers [51]. Therefore, from the perspective of embedding the behavior of star-rated hotel staff in a social environment, it is also necessary to introduce influencing factors from outside hotels. This point and the above two theories complement each other, and as such construct the theoretical basis of this research.

\subsection{Exploratory Identification Results}

Orientated by the theoretical basis of this research, the variables triggering low-carbon behavior among staff in the hotel industry were collected, but they are variegated and dispersed in the existing literature (shown in the third column in Table 2). Therefore, this paper employed grounded theory, which was regarded as creating an "explanation of action" [52] to identify six influencing factors of relevance for our research aim: strategic orientation, low-carbon managerial activities, personal norms, perceived behavior control, social norms, and consumer attitude. In order to ensure the systematic and comprehensive factor identification in an exploratory and inductive process, twelve experts from different levels of star-rated hotels in Eastern China were interviewed in-depth and face-to-face for further confirmation between July and August 2018. Purposive sampling was administered for interviewee selection according to their potential contributions to the topics we expected to broach. All chosen interviewees had at least five years of experience in the lodging industry, including four 
upper managers and eight middle-level managers. Among them, three were from five-star hotels, four from four-star hotels, and five from three-star hotels. Under the data saturation principle followed in the study of [53], no updated information was gained from the interview with the twelfth interviewee, indicating that data were saturated after twelve interviews with no more interviewees needed after this point. According to the above research process, a set of six influencing factors of low-carbon staff behavior in star-rated hotels was finally identified (Table 2).

Table 2. Identification of factors influencing low-carbon staff behavior in star-rated hotels.

\begin{tabular}{|c|c|c|}
\hline Category & Factors & Existing Variables \\
\hline Internal factors & $\begin{array}{l}\text { Low-carbon managerial activities } \\
\text { Personal norms } \\
\text { Perceived behavior control }\end{array}$ & $\begin{array}{c}\text { Corporate social responsibility } \\
\text { Low-carbon corporate culture } \\
\text { Low-carbon corporate image } \\
\text { Proactive environmental strategy } \\
\text { Top management support } \\
\text { System of rewards and penalties } \\
\text { Available resources for implementation } \\
\text { Green training } \\
\text { Disposal of throw-away products } \\
\text { Low-carbon publicity } \\
\text { Communication and interactions } \\
\text { Individual green values } \\
\text { Environmental attitude } \\
\text { Pro-environmental reputation } \\
\text { Environmental will and initiatives } \\
\text { Low-carbon knowledge } \\
\text { Time and energy } \\
\text { Individual self-competitiveness }\end{array}$ \\
\hline External factors & Consumer attitude & $\begin{array}{c}\text { Marketing policy } \\
\text { Laws, standards and regulations } \\
\text { Government supervision } \\
\text { Mess media } \\
\text { Nongovernmental organization supervision } \\
\text { Pressure from peer hotels } \\
\text { Willingness to cooperate with low-carbon behavior } \\
\text { Demanding sustainable products } \\
\text { Check-in satisfaction and loyalty } \\
\text { Intention towards green hotel visit }\end{array}$ \\
\hline
\end{tabular}

\subsection{Hypotheses Proposed}

\subsubsection{Strategic Orientation}

In the lodging industry, it is not only the "right thing to do", but also "the smart thing to do" for hotel enterprises to attract customers and dominate marketplaces [54]. Hence, understanding strategic orientation is a critical marketing strategy for hotels, as it creates proper behaviors that enable the continuous superior performance of a hotel business [55,56]. Many high-end hotels have gradually realized the need to focus not only on profit promotion, but also on decision making that is ethically and socially acceptable in relation to the environment involved [57], making strategic orientation largely mirror cooperate social responsibility. Thus, the first hypothesis is formulated as follows:

Hypothesis 1. Strategic orientation exerts a direct positive effect on staff's low-carbon behaviors in star-rated hotels.

\subsubsection{Low-Carbon Managerial Activities}

Hotel managers play an important role in implementing appropriate sustainability practices [58]. In the current literature, the dimension of study of the environmental management practice of hotels has expanded to diversity based on a plurality of management activities, such as communication and education, marketing activities, and organizational and operational practices [59]. Additionally, 
as proposed in the research of [60], low-carbon managerial actions, e.g., improvements in facilities or materials, tax incentives, and other energy-saving programs, are of great benefit during the operation process of hotel enterprises. Accordingly, the following hypothesis is then proposed:

Hypothesis 2. Low-carbon managerial activities exert a direct positive effect on staff's low-carbon behaviors in star-rated hotels.

\subsubsection{Personal Norms}

Personal norms, as critical determinants of pro-environmental behaviors, refer to the expectations people hold for themselves [19,61]. Gao et al., (2017) proved that these norms derived from moral responsibility or the obligation to perform/refrain from specific behaviors [48]. In other words, people behave in a way that they believe is morally right; for instance, employees tend to be willing to follow energy-saving actions regulated by hotels. Harland et al., (2007) also asserted that pro-environmental behaviors would be encouraged when people showed moral obligation towards environmental issues [62]. Thus, our model proposes the assumption that personal norms influence low-carbon behavior in star-rated hotels:

Hypothesis 3. Personal norms exert a direct positive effect on low-carbon behavior among staff in star-rated hotels.

\subsubsection{Perceived Behavior Control}

Perceived behavior control represents the extent of volition people perceive that they have and whether they feel they can actually perform an action [63]. This means the more time, knowledge, energy, skills, resources and opportunities someone believes they possess, the fewer obstacles they may expect in carrying out the behavior [64]. As Kollmuss and Agyeman (2002) indicated, people took environmental protection actions only if they mastered relevant knowledge of environmental issues and behaviors that may cause eco-problems [65]. Similarly, Donald et al. (2014) found that if individuals had higher levels of knowledge and skills to save energy, they would focus on energy conservation in their daily life [66]. This evidence is therefore tested with the following hypothesis:

Hypothesis 4. Perceived behavior control exerts a direct positive effect on staff's low-carbon behaviors in star-rated hotels.

\subsubsection{Social Norms}

Social norms represent the restraint effect of social pressure on each individual, featured as mandatory [67]. There is currently a large amount of evidence that social norms nudge people towards a wide range of environmental choices and behaviors [68,69]. It was found that the social pressure caused by social norms had a great impact on behaviors of energy use and personal low-carbon practice [70]. Another study by Nolan et al., (2008) showed that people began to increase towel reuse in guest rooms after being informed about the reuse condition by others [71]. Social norms in the lodging sector normally cover hotel rules and regulations, public environmental supervision, peer competitiveness from other hotels, the values that social groups and members acknowledge, etc. As people do not act as in isolation, they are likely to be easily affected by normative influences and surrounding contexts [72]. Thus, the paper tests the following hypothesis:

Hypothesis 5. Social norms exert a direct positive effect on low-carbon behavior among staff in star-rated hotels.

\subsubsection{Consumer Attitude}

Attitude is how an individual feels about their behaviors (e.g., positive or negative) [73]. Star-rated hotels place consumers at their center since their attitudes are a pivotal factor for hotel survival, which is strongly associated with repeat sales, positive word of mouth, and guest loyalty [74]. Increasing attention being paid to the environment and sustainability by consumers could lead 
hoteliers to upgrade their business by adopting low-carbon hospitality management [2]. Namely, if a star-rated hotel wants to gain and keep guests with positive attitudes towards low-carbon operation, hoteliers will undoubtedly make great efforts to conduct a wide spectrum of low-carbon practices, such as green product procurement, energy and water savings, and waste recycling, to meet the demand of sustainability-sensitive guest segments [34,75-77]. Hence, the following hypothesis is proposed:

Hypothesis 6. Consumer attitude exerts a direct positive effect on staff's low-carbon behaviors in star-rated hotels.

Based on the above hypotheses, the theoretical model to be tested in our empirical study was constructed as shown in Figure 1.

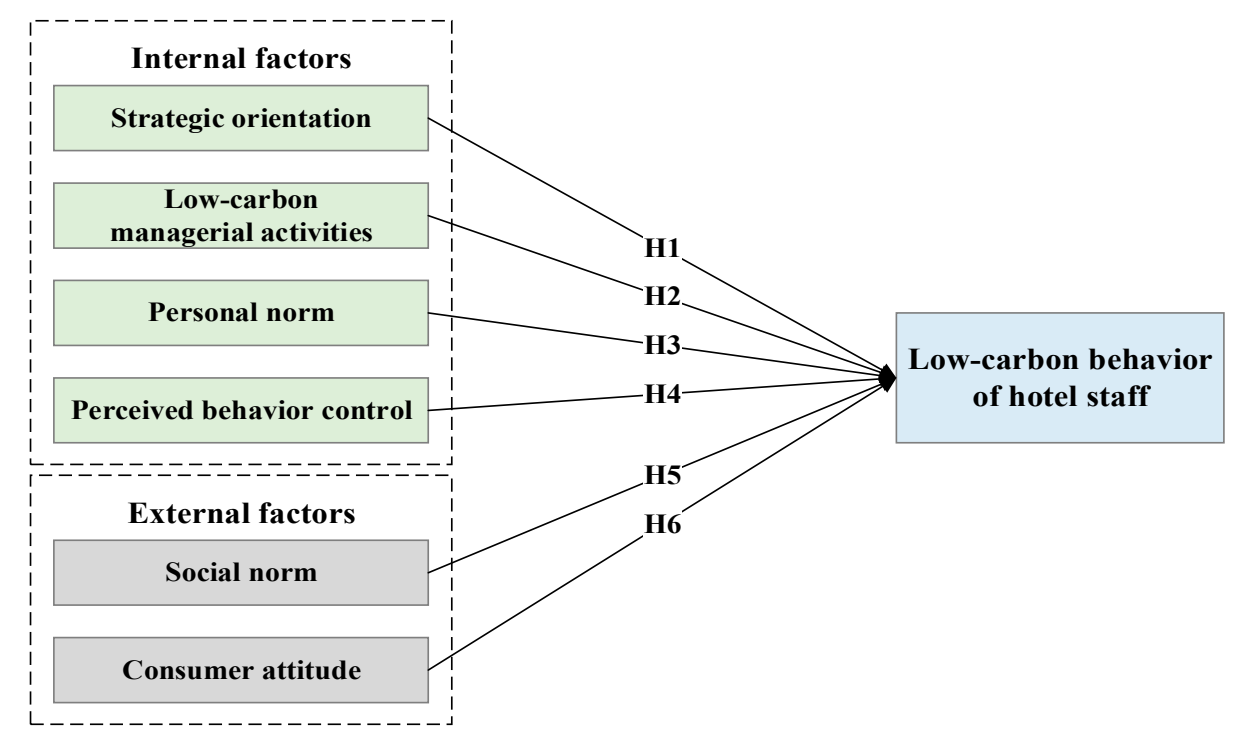

Figure 1. Theoretical model and hypotheses. (Note: H stands for hypothesis).

\section{Methodology}

\subsection{Questionnaire Design}

After a series of preliminary research tasks and a pilot study, behavioral and factor-related questions were designed based on five of the low-carbon behaviors of hotel staff [30-32] and six of the identified influencing factors [8,78-82]. A pilot study was conducted in Nanjing, one of the cities in the targeted study area, and fifty staff volunteers in star-rated hotels took part in it in August 2018. Moreover, to further ensure the content validity of the designed questionnaire, it was also reviewed by experts in the abovementioned expert interviews. Based on these results, questions that were unclear or problematic were revised.

The final questionnaire covers three main sections: (1) the socio-demographics of respondents, as well as star ratings of the hotels they work for and some basic hotel information; (2) the degree of impact of the six factors influencing staff's low-carbon behaviors in star-rated hotels; and (3) the actual implementation of low-carbon behavior among staff for star-rated hotels. Notably, the behaviors in this research signified self-reported behaviors regarding low-carbon design, low-carbon procurement, low-carbon decision making, low-carbon operation and low-carbon execution, which are usually adopted as proxies of actual human activities due to their high efficiency and low cost [83]. Twenty-nine items were measured, depending on seven latent variables: three for strategic orientation (SO), six for low-carbon managerial activities (LCM), three for personal norms (PN), three for perceived behavior control (PBC), six for social norms (SN), three for consumer attitude (CA), and five for low-carbon behavior (LCB), as shown in Table 3. All items in Sections 2 and 3 of the questionnaire were rated on a seven-point Likert scale from which respondents were asked to rate from 1 ("strong disagreement") 
to 7 ("strong agreement") how well each measurement described their experience and practice with these factors.

\subsection{Data Collection}

According to the Star Rating and Evaluation of Tourist Hotels (GB/T14308-2010), released by the National Tourism Administration in China, a five-star rating system was applied to evaluate the star ratings of different hotels according to hotel architectural scales, service equipment, service quality, management levels, etc. (Figure 2). Namely, hotels could be classified into five rating levels from one star-rated hotels to five star-rated hotels, which means that the more stars a hotel has, the higher rating level it belongs to. It was found in the first-stage field investigation that hotels rated as having no more than three stars were not commonly mature in regard to their low-carbon practice: for example, their employees had a weak low-carbon awareness, they had less advanced energy-saving facilities and equipment, less green publicity, and so forth. Therefore, considering the validity of answers given by hotel staff in the survey, the hotels rated as having three and more stars were selected as star-rated hotels in this research.

\begin{tabular}{|c|c|c|c|c|c|}
\hline \multirow{2}{*}{ Star rating levels } & \multicolumn{4}{|c|}{ Hotel characteristics } & \multirow{2}{*}{ Targeted guests } \\
\hline & $\begin{array}{l}\text { Market } \\
\text { position }\end{array}$ & Facility & Service & Function & \\
\hline One star-rated hotel & \multicolumn{4}{|c|}{$\begin{array}{l}\text { Quite cheap hotel with very simple facilities, providing hotel } \\
\text { basic services, able to meet the simplest demands of guests for } \\
\text { accommodation and catering }\end{array}$} & Guests with very low income \\
\hline Two star-rated hotel & \multicolumn{4}{|c|}{$\begin{array}{l}\text { Budget hotel with simple facilities, providing relative good } \\
\text { services and integrated service establishments like shops or } \\
\text { barbershops apart from accommodation and catering }\end{array}$} & Guests with low income \\
\hline Three star-rated hotel & \multicolumn{4}{|c|}{$\begin{array}{l}\text { Mid-range hotel with well-equipped facilities, providing good } \\
\text { services and more integrated service establishments like } \\
\text { meeting rooms, bars, cafés above the two-star criteria }\end{array}$} & Guests with moderate income \\
\hline Four star-rated hotel & \multicolumn{4}{|c|}{$\begin{array}{l}\text { Quality hotel with excellent facilities, providing quality } \\
\text { services, complete integrated service establishments and elegant } \\
\text { surroundings above the three-star criteria }\end{array}$} & Guests with high income \\
\hline Five star-rated hotel & \multicolumn{4}{|c|}{$\begin{array}{l}\text { Luxury hotel with excellent and luxurious facilities, providing } \\
\text { high-level quality services and quite complete integrated } \\
\text { service establishments above the four-star criteria }\end{array}$} & Guests with very high income \\
\hline
\end{tabular}

Figure 2. Criteria for classifying hotels with different stars. 
Table 3. Factors and measurement items for low-carbon staff behavior adoption in star-rated hotels.

\begin{tabular}{|c|c|c|}
\hline Latent Factors & Code & Items for Construct \\
\hline \multirow{3}{*}{$\begin{array}{c}\text { Strategic } \\
\text { orientation (SO) }\end{array}$} & SO1 & Hotel leadership places an emphasis on low carbon/environmental protection and considers both as being part of a social mission. \\
\hline & SO2 & Hotels have a low-carbon enterprise culture and brand image that are praised. \\
\hline & $\mathrm{SO} 3$ & Hotels formulate their own low-carbon management regulations. \\
\hline \multirow{6}{*}{$\begin{array}{c}\text { Low-carbon } \\
\text { managerial } \\
\text { activities (LCM) }\end{array}$} & LCM1 & Hoteliers provide rewards or penalty to employees according to their performance in relation to low-carbon practices. \\
\hline & LCM2 & Low energy-efficiency facilities are regularly phased out, and energy-saving reforms are actively conducted with new technologies. \\
\hline & LCM3 & Regular training is provided for hotel staff in order to popularize knowledge of low-carbon practices in hotels. \\
\hline & LCM4 & Disposable toiletries (e.g., prepackaged toothbrushes, toothpaste, shampoo, soap, combs, and slippers) are slimmed down, with reusable ones provided instead. \\
\hline & LCM5 & Low-carbon publicity activities are frequently carried out, such as putting up banners or slogans about environmental protection on the walls and tip cards with energy-saving reminders in guests' rooms \\
\hline & LCM6 & Hoteliers organize or participate in frequent voluntary activities regarding low-carbon development for communication and interactions with other peer enterprises. \\
\hline \multirow{3}{*}{$\begin{array}{l}\text { Personal norms } \\
\quad \text { (PN) }\end{array}$} & PN1 & Staff in hotels assume social responsibility for emission reductions and environmental protection. \\
\hline & PN2 & Staff in hotels would like to boost their personal reputations and relationship with others through low-carbon behavior implementation. \\
\hline & PN3 & Staff in hotels show great willingness towards low-carbon practices and environmental protection. \\
\hline \multirow{3}{*}{$\begin{array}{c}\text { Perceived } \\
\text { behavior control } \\
\text { (PBC) }\end{array}$} & PBC1 & Staff in hotels have a high-level knowledge and understanding of reducing $\mathrm{CO}_{2}$ emissions. \\
\hline & $\mathrm{PBC2}$ & Staff in hotels have adequate time and energy to practice low-carbon behaviors. \\
\hline & РВС3 & Staff in hotels face great demand to enhance their own competitiveness through low-carbon behavior implementation. \\
\hline \multirow{5}{*}{ Social norms (SN) } & SN1 & Macro-level market policies (e.g., energy price guidance, ladder-type electricity pricing, etc.) obviously influence low-carbon practice in hotels. \\
\hline & SN2 & Norms and standards regarding hotel management provide effective references for low-carbon practice. \\
\hline & SN3 & Supervision from social administrative departments such as environmental protection agencies leads hotels towards low-carbon behavior implementation for social sustainability. \\
\hline & SN5 & There is a low-carbon environmental protection atmosphere throughout the whole of society, with the focus increasing on low-carbon practices in the hotel industry. \\
\hline & SN6 & Peer competitiveness brings so much pressure to hotels that low-carbon practice becomes an indispensable part. \\
\hline \multirow{3}{*}{$\begin{array}{l}\text { Consumer attitude } \\
\text { (CA) }{ }^{1}\end{array}$} & CA1 & Consumers support the low-carbon behavior of hotels and are willing to cooperate with them. \\
\hline & CA2 & Consumers have great demand for low-carbon/green products in hotels. \\
\hline & CA3 & Consumers always offer their comments to improve the low-carbon/green behavior implementation in hotels. \\
\hline \multirow{5}{*}{$\begin{array}{c}\text { Low-carbon } \\
\text { behavior (LCB) }\end{array}$} & LCB1 & Operations managers get involved in the design of low-carbon strategies such as those related to water saving, renewable use, operating facilities, etc. \\
\hline & LCB2 & Low-carbon green products are the first to be purchased in the procurement process. \\
\hline & LCB3 & Investment in low-carbon practice has increased due to decision making. \\
\hline & LCB4 & Hoteliers implement low-carbon strategies into the whole process of operational management. \\
\hline & LCB5 & Employees perform their duties by actively executing low-carbon practices at work. \\
\hline
\end{tabular}

attitude on low-carbon staff behavior was rated by staff. 
The formal questionnaire survey was administered from September to October 2018. Questionnaires were distributed to staff (including front-line staff members and managers) from star-rated hotels in typical metropolises (municipalities or provincial capitals) of Eastern China, including Beijing, Shanghai, Hangzhou, and Nanjing (Figure 3). The per capita carbon emissions in these megacities are usually higher than core cities of other nations like London, Singapore, and Tokyo [84,85], needing more attention when developing low-carbon strategies.

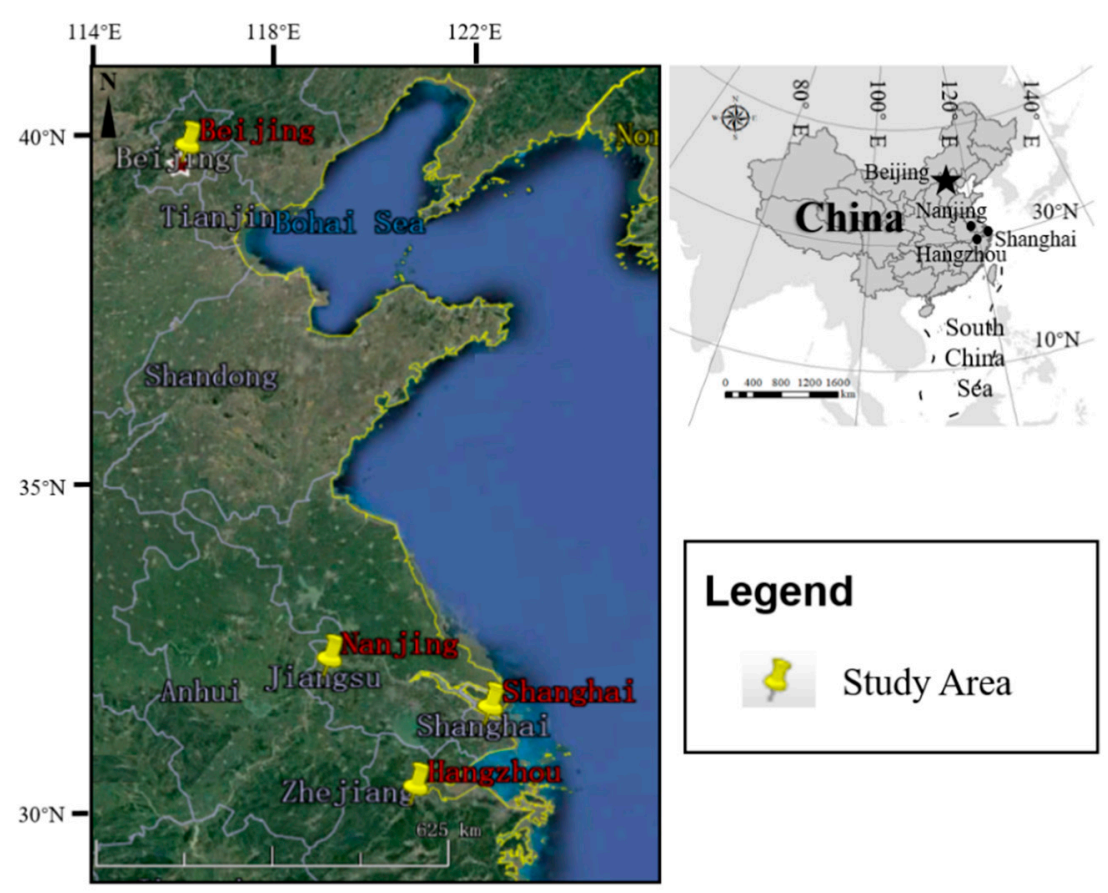

Figure 3. Study areas of the questionnaire survey.

It is worth mentioning that the connotation of low-carbon behavior among staff in our research is rather different from what is generally understood, especially in the fields of medical health. Instead, it refers to what actions hotel staff could take to lead the green, sustainable and low-carbon development of star-rated hotels, which has nothing to do with any ethical issues related to the human body. Therefore, we must stress that the present research objective is not targeted at individual behavior that involves human subjects, human material, human tissues or human data. Another thing that we must note is that, prior to the formal questionnaire survey in the investigated star-rated hotels, we communicated adequately with the hotels' direct supervisors to confirm whether data collection would be permitted in their hotels. Then, all the staff from the investigated star-rated hotels were informed of the study purpose and intent with the coordination of the hotels' direct supervisors. Moreover, they were previously promised that their answers would not be leaked out to any others and that their experience would be fully anonymous with no private information identifying them included. After such a procedure, which played the same role as an ethical statement, a total of 500 hotel staff members agreed and volunteered to participate in the survey. Finally, there were 440 valid responses returned both offline $75.5 \%$ (332) and online $24.5 \%$ (108), resulting in an effective response rate of $88.0 \%$. This questionnaire survey gave priority to offline collection and was supplemented with online collection, because- -helped by hotels' direct supervisors—-we got in in direct touch with some front-line staff members who agreed to participate in our survey through the internet. The socio-demographic information of the respondents is shown in Table 4. 
Table 4. Summary of respondent socio-demography $(n=440)$.

\begin{tabular}{|c|c|c|c|}
\hline \multicolumn{2}{|c|}{ Characteristics } & \multirow{3}{*}{$\begin{array}{c}n \\
251 \\
189\end{array}$} & \multirow{3}{*}{$\begin{array}{c}\text { Proportion (\%) } \\
57.0 \% \\
43.0 \% \\
\end{array}$} \\
\hline & Male & & \\
\hline Gender & Female & & \\
\hline \multirow{4}{*}{ Age } & $<25$ & 62 & $14.2 \%$ \\
\hline & $25-30$ & 91 & $20.8 \%$ \\
\hline & $31-40$ & 160 & $36.5 \%$ \\
\hline & $>40$ & 125 & $28.5 \%$ \\
\hline \multirow{4}{*}{ Education level } & Senior school or below & 131 & $29.8 \%$ \\
\hline & Junior college & 174 & $39.5 \%$ \\
\hline & College & 126 & $28.6 \%$ \\
\hline & Master or above & 9 & $2.1 \%$ \\
\hline \multirow{4}{*}{ Occupation in hotel } & Service staff member & 122 & $27.7 \%$ \\
\hline & Department manager & 249 & $56.6 \%$ \\
\hline & Chief inspector & 47 & $10.7 \%$ \\
\hline & Managing director or above & 22 & $5.0 \%$ \\
\hline \multirow{4}{*}{ Working experience in hotel industry } & $<5$ years & 144 & $32.7 \%$ \\
\hline & 5-10 years & 145 & $33.0 \%$ \\
\hline & $11-20$ years & 116 & $26.4 \%$ \\
\hline & $>20$ years & 35 & $7.9 \%$ \\
\hline \multirow{3}{*}{ Number of hotels with different stars } & Three star-rated hotels & 131 & $29.8 \%$ \\
\hline & Four star-rated hotels & 189 & $43.0 \%$ \\
\hline & Five star-rated hotels & 120 & $27.2 \%$ \\
\hline
\end{tabular}

\subsection{Data Analysis}

Structural equation modeling (SEM) is a method widely used in the domain of behavioral science [86-89]. It can not only estimate a series of independent multiple regression equations simultaneously, but also incorporate latent variables by taking measurement errors into account. Superior to multiple regression analysis, SEM is robust to measurement errors and model misspecification [90]. Hence, it was selected in this research to analyze the impact of influencing factors on staff's low-carbon behaviors in star-rated hotels. The maximum likelihood method was applied in SEM, for the use of which the normality assumption should not be severely violated [91]. Based on such a precondition, descriptive statistics analysis and reliability analysis were initially conducted assisted by IBM SPSS Statistics (V.23) (IBM, Armonk, NY, USA). IBM SPSS Amos (V.24) (IBM, Armonk, NY, USA) was then employed to build and modify models and conduct confirmatory factor analysis.

\section{Results}

\subsection{Descriptive Statistics}

The mean values (M) and standard deviations (SD) of construct items are obtained as listed in Table 5. All M-values are greater than five, ranging from the lowest at 5.63 (CA3, referring to consumer comments) to the highest at 6.45 (SN1, referring to macro-level market policies), indicating an overall positive response to the considered constructs. The normality assumption test is the premise of the utilization of the maximum likelihood method in confirmatory factor analysis, and severe abnormally distributed samples, suggesting absolute skewness $(S k)$ values greater than three and absolute kurtosis $(K)$ values greater than 10 [92], are not acceptable. As shown in Table 5, the skewness values and kurtosis values of construct items were mostly close to zero, with no value falling out of the above constraint interval (i.e., $S k \in(-3,3) \cap K \in(-10,10)$ ), which implied that the sample data were generally normally distributed. Thus, the maximum likelihood method could be used for estimation in further analyses. 
Table 5. Descriptive statistics of construct items.

\begin{tabular}{|c|c|c|c|c|}
\hline \multirow{2}{*}{ Construct Item } & \multicolumn{4}{|c|}{ Overall Sample $(n=440)$} \\
\hline & $\mathbf{M}$ & SD & $S k$ & $K$ \\
\hline SO1 & 6.18 & 0.987 & -1.032 & 0.834 \\
\hline $\mathrm{SO} 2$ & 6.33 & 0.855 & -1.149 & 1.141 \\
\hline $\mathrm{SO} 3$ & 6.45 & 0.839 & -1.901 & 5.599 \\
\hline LCM1 & 5.97 & 1.265 & -1.129 & 0.668 \\
\hline LCM2 & 6.20 & 1.034 & -1.348 & 1.199 \\
\hline LCM3 & 6.07 & 1.196 & -1.207 & 0.657 \\
\hline LCM4 & 6.04 & 1.237 & -1.046 & 0.205 \\
\hline LCM5 & 6.12 & 1.138 & -1.198 & 0.480 \\
\hline LCM6 & 6.23 & 1.108 & -1.417 & 1.234 \\
\hline PN1 & 5.75 & 1.065 & -0.480 & -0.558 \\
\hline PN2 & 5.78 & 1.034 & -0.386 & -0.762 \\
\hline PN3 & 5.74 & 1.085 & -0.487 & -0.561 \\
\hline $\mathrm{PBC1}$ & 5.86 & 1.017 & -0.651 & -0.125 \\
\hline PBC2 & 5.74 & 1.111 & -0.550 & -0.579 \\
\hline РBC3 & 5.70 & 1.159 & -0.641 & -0.418 \\
\hline SN1 & 6.45 & 0.828 & -1.545 & 1.993 \\
\hline SN2 & 6.31 & 0.930 & -1.364 & 1.423 \\
\hline SN3 & 6.30 & 1.020 & -1.512 & 1.661 \\
\hline SN4 & 6.24 & 1.076 & -1.457 & 1.344 \\
\hline SN5 & 6.12 & 1.197 & -1.225 & 0.801 \\
\hline SN6 & 6.18 & 1.117 & -1.279 & 1.285 \\
\hline CA1 & 5.78 & 1.111 & -0.622 & -0.245 \\
\hline CA2 & 5.77 & 1.149 & -0.697 & -0.234 \\
\hline CA3 & 5.63 & 1.173 & -0.559 & -0.371 \\
\hline LCB1 & 6.37 & 0.974 & -1.506 & 2.074 \\
\hline LCB2 & 6.25 & 1.020 & -1.400 & 1.592 \\
\hline LCB3 & 6.29 & 1.043 & -1.409 & 1.350 \\
\hline LCB4 & 6.42 & 1.002 & -2.012 & 4.329 \\
\hline LCB5 & 6.32 & 1.043 & -1.723 & 2.990 \\
\hline
\end{tabular}

Note: $\mathrm{M}=$ mean; $\mathrm{SD}=$ standard deviation; $S k=$ skewness value; $K=$ kurtosis value. $\mathrm{SO}=$ strategic orientation; $\mathrm{LCM}=$ low-carbon managerial activities; $\mathrm{PN}=$ personal norms; $\mathrm{PBC}=$ perceived behavior control; $\mathrm{SN}=$ social norms; $\mathrm{CA}=$ consumer attitude; $\mathrm{LCB}=$ low-carbon behavior.

\subsection{Measurement Model Evaluation}

\subsubsection{Reliability Analysis}

To test the internal consistency of the constructs, Cronbach's $\alpha(0-1)$ is normally used, based on the average inter-item correlation. Reliability is acceptable when the $\alpha$ value is more than 0.7 [93]. Cronbach's $\alpha$ of each construct and the overall sample were analyzed. All $\alpha$ values are more than 0.8 (most of them $>0.9$ ), indicating the high reliability of the collected data (Table 6). Furthermore, composite reliability (CR) among constructs ranges from 0.826 to 0.960 , all values of which exceed the standard minimum limit of 0.7, suggesting stronger reliability than Cronbach's alpha estimation [94].

Table 6. Results of the reliability test.

\begin{tabular}{cccc}
\hline Construct & Cronbach's $\boldsymbol{\alpha}^{\mathbf{a}}$ & CR & No. of Items \\
\hline Strategic orientation (SO) & 0.820 & 0.826 & 3 \\
Low-carbon managerial activities (LCM) & 0.928 & 0.929 & 6 \\
Personal norms (PN) & 0.942 & 0.942 & 3 \\
Perceived behavior control (PBC) & 0.953 & 0.954 & 3 \\
Social norms (SN) & 0.940 & 0.943 & 6 \\
Consumer attitude (CA) & 0.958 & 0.960 & 3 \\
Low-carbon behavior (LCB) & 0.930 & 0.930 & 5 \\
\hline
\end{tabular}

Note: $\mathrm{CR}=$ composite reliability. ${ }^{\text {a }}$ Overall Cronbach's $\alpha=0.963$. 


\subsubsection{Validity Analysis}

Considering that the preliminary factor identification process is exploratory and inductive, exploratory factor analysis (EFA) is needed to provide strong evidence in order to verify the high-quality questionnaire development in this research. Therefore, pre-Principal Component Analysis (PCA) was used to carry out EFA. The rotated component matrix and extraction details are both shown in Table 7 . The items were finally classified into six corresponding factors according to the criterion of the factor loading's absolute value larger than 0.5 [95]. For better visualization, the values below such a threshold are excluded in Table 7. Notably, the classification results in Table 7 fully correspond to the previous identification results of influencing factors, illustrating that the factor identification and questionnaire design are rigorous and convincing. Overall, the sample data meet the requirements for SEM analysis.

Table 7. Rotated component matrix.

\begin{tabular}{ccccccc}
\hline \multirow{2}{*}{ Construct Item } & \multicolumn{7}{c}{ Components } \\
\cline { 2 - 7 } & $\mathbf{1}$ & $\mathbf{2}$ & $\mathbf{3}$ & $\mathbf{4}$ & $\mathbf{5}$ & $\mathbf{6}$ \\
\hline SO1 & 0.773 & - & - & - & - & - \\
SO2 & 0.780 & - & - & - & - & - \\
SO3 & 0.665 & - & - & - & - & - \\
LCM1 & - & 0.788 & - & - & - & - \\
LCM2 & - & 0.681 & - & - & - & - \\
LCM3 & - & 0.771 & - & - & - & - \\
LCM4 & - & 0.730 & - & - & - & - \\
LCM5 & - & 0.709 & - & - & - & - \\
LCM6 & - & 0.655 & - & - & - & - \\
PN1 & - & - & 0.853 & - & - & - \\
PN2 & - & - & 0.858 & - & - & - \\
PN3 & - & - & 0.842 & - & - & - \\
PBC1 & - & - & - & 0.887 & - & - \\
PBC2 & - & - & - & 0.905 & - & - \\
PBC3 & - & - & - & 0.870 & - & - \\
SN1 & - & - & - & - & 0.713 & - \\
SN2 & - & - & - & - & 0.789 & - \\
SN3 & - & - & - & - & 0.839 & - \\
SN4 & - & - & - & - & 0.857 & - \\
SN5 & - & - & - & - & 0.781 & - \\
SN6 & - & - & - & - & 0.688 & - \\
CA1 & - & - & - & - & - & 0.628 \\
CA2 & - & - & - & - & - & 0.649 \\
CA3 & - & - & - & - & - & 0.616 \\
\hline CNyyyyyyy & & - & - & - & - \\
\hline
\end{tabular}

Note: Extraction method: Principal Component Analysis (PCA); Rotation: varimax rotation standardized by Kaiser (rotation is convergent after the eighth iteration); cumulative variance contribution: 82.01\%; Kaiser-Meyer-Olkin (KMO) statistic: 0.942 (very acceptable); Bartlett's Test of Sphericity probability: 0.000.

The goodness-of-fit indices of the initial measurement model are indicated in Table 8 , all of which met the acceptable thresholds of model fitness adapted from the studies of Leung and Chan (2007), as well as Qureshi and Kang (2015) [96,97]. This ensures the appropriateness of the following confirmatory factor analysis (CFA) for the validity test. Through the CFA, the measurement items with standardized factor loadings (FL) less than 0.5 need to be eliminated [98]. None of the items were deleted in this research, since all their standardized factor loadings exceeded the recognized value $(p<0.001)$. Apart from the factor loading test, converged validity and discriminant validity were then tested. For the constructs in Table 8, all the average variances extracted (AVE) passed the cut-off value of 0.5 [99], with a minimum of 0.614 and a maximum of 0.888 , which indicated the strong convergent validity of items for the same construct. 
Table 8. Converged validity and goodness-of-fit of the measurement model.

\begin{tabular}{|c|c|c|c|c|c|c|c|c|}
\hline \multicolumn{3}{|c|}{ Construct } & Item & & FL & & AVE & \\
\hline \multirow{4}{*}{\multicolumn{3}{|c|}{$\mathrm{SO}$}} & & & & & 0.614 & \\
\hline & & & $\mathrm{SO} 1$ & & $0.835^{* * *}$ & & & \\
\hline & & & $\mathrm{SO} 2$ & & $0.793 * * *$ & & & \\
\hline & & & $\mathrm{SO} 3$ & & $0.718^{* * *}$ & & & \\
\hline \multirow{7}{*}{\multicolumn{3}{|c|}{ LCM }} & & & & & 0.687 & \\
\hline & & & LCM1 & & $0.789 * * *$ & & & \\
\hline & & & LCM2 & & $0.828^{* * *}$ & & & \\
\hline & & & LCM3 & & $0.870^{* * *}$ & & & \\
\hline & & & LCM4 & & $0.785^{* * *}$ & & & \\
\hline & & & LCM5 & & $0.884^{* * *}$ & & & \\
\hline & & & LCM6 & & $0.813^{* * *}$ & & & \\
\hline \multirow{4}{*}{\multicolumn{3}{|c|}{$\mathrm{PN}$}} & & & & & 0.845 & \\
\hline & & & PN1 & & $0.921^{* * *}$ & & & \\
\hline & & & PN2 & & $0.912 * * *$ & & & \\
\hline & & & PN3 & & $0.924^{* * *}$ & & & \\
\hline \multirow{4}{*}{\multicolumn{3}{|c|}{ PBC }} & & & & & 0.874 & \\
\hline & & & PBC1 & & $0.916^{* * *}$ & & & \\
\hline & & & PBC2 & & $0.958^{* * *}$ & & & \\
\hline & & & PBC3 & & $0.930^{* * *}$ & & & \\
\hline \multirow{7}{*}{\multicolumn{3}{|c|}{$\mathrm{SN}$}} & & & & & 0.735 & \\
\hline & & & SN1 & & $0.760 * * *$ & & & \\
\hline & & & SN2 & & $0.864^{* * *}$ & & & \\
\hline & & & SN3 & & $0.904 * * *$ & & & \\
\hline & & & SN4 & & $0.903^{* * *}$ & & & \\
\hline & & & SN5 & & $0.866^{* * *}$ & & & \\
\hline & & & SN6 & & $0.838^{* * *}$ & & & \\
\hline \multirow{4}{*}{\multicolumn{3}{|c|}{ CA }} & & & & & 0.888 & \\
\hline & & & CA1 & & $0.958^{* * *}$ & & & \\
\hline & & & CA2 & & $0.972 * * *$ & & & \\
\hline & & & CA3 & & $0.895^{* * *}$ & & & \\
\hline \multirow{6}{*}{\multicolumn{3}{|c|}{ LCB }} & & & & & 0.728 & \\
\hline & & & LCB1 & & $0.801 * * *$ & & & \\
\hline & & & LCB2 & & $0.891^{* * *}$ & & & \\
\hline & & & LCB3 & & $0.876^{* * *}$ & & & \\
\hline & & & LCB4 & & $0.810 * * *$ & & & \\
\hline & & & LCB5 & & $0.884^{* * *}$ & & & \\
\hline $\mathrm{X}^{2} / \mathrm{df}$ & $p$ & GFI & RMSEA & TLI & IFI & CFI & PNFI & PGFI \\
\hline 2.557 & 0.000 & 0.872 & 0.060 & 0.952 & 0.958 & 0.958 & 0.818 & 0.713 \\
\hline
\end{tabular}

Note: FL = standardized factor loading; AVE = average variance extracted; GFI = goodness-of-fit index; AGFI = adjusted goodness-of-fit index; RMSEA = root mean square error of approximation; TLI = Tucker-Lewis Index; $\mathrm{IFI}=$ incremental fit index; $\mathrm{CFI}=$ comparative fit index; $\mathrm{PNFI}=$ parsimony normed-fit index; $\mathrm{PGFI}=$ parsimony goodness-of-fit index. ${ }^{* * *} p<0.001$.

The discriminant validity was subsequently tested, in which the square root of the AVE for a given construct was compared with the correlations between such a construct and all others [100]. Table 9 shows that the square root of each AVE (diagonal elements) is greater than the related inter-construct correlations (off-diagonal elements) in the corresponding rows and columns, indicating adequate discriminant validity for all the constructs. From the above, the measurement model evaluation shows high reliability and validity of constructs and corresponding items for further assessment of the structural model. 
Table 9. Correlation matrix and discriminant validity for the constructs.

\begin{tabular}{cccccccc}
\hline Construct & SO & LCM & PN & PBC & SN & CA & LCB \\
\hline SO & $(0.783)$ & - & - & - & - & - & - \\
LCM & $0.724^{* * *}$ & $(0.829)$ & - & - & - & - & - \\
PN & $0.450^{* * *}$ & $0.416^{* * *}$ & $(0.919)$ & - & - & - & - \\
PBC & $0.349^{* * *}$ & $0.449^{* * *}$ & $0.655^{* * *}$ & $(0.935)$ & - & - & - \\
SN & $0.672^{* * *}$ & $0.817^{* * *}$ & $0.359^{* * *}$ & $0.412^{* * *}$ & $(0.857)$ & - & - \\
CA & $0.440^{* * *}$ & $0.448^{* * *}$ & $0.774^{* * *}$ & $0.811^{* * *}$ & $0.402^{* * *}$ & $(0.942)$ & - \\
LCB & $0.768^{* * *}$ & $0.815^{* * *}$ & $0.367^{* * *}$ & $0.447^{* * *}$ & $0.754^{* * *}$ & $0.413^{* * *}$ & $(0.853)$ \\
\hline
\end{tabular}

Note: Bracketed values are the square roots of the average variance extracted. ${ }^{* * *} p<0.001$.

\subsection{Structural Model Assessment}

\subsubsection{Results of Model Modification and Test}

The initial structural model (M1) was constructed using Amos 24 after the acceptable evaluation of the measurement model. The interactions of constructs (latent variables) and relevant items (observed variables) are listed in more detail (Figure 4). For effective model identification in confirmatory factor analysis, the unmeasured latent variables were applied to a set measurement scale and to capture the common latent factors by constraining the given paths equal to 1 [101], shown in Figure 4.

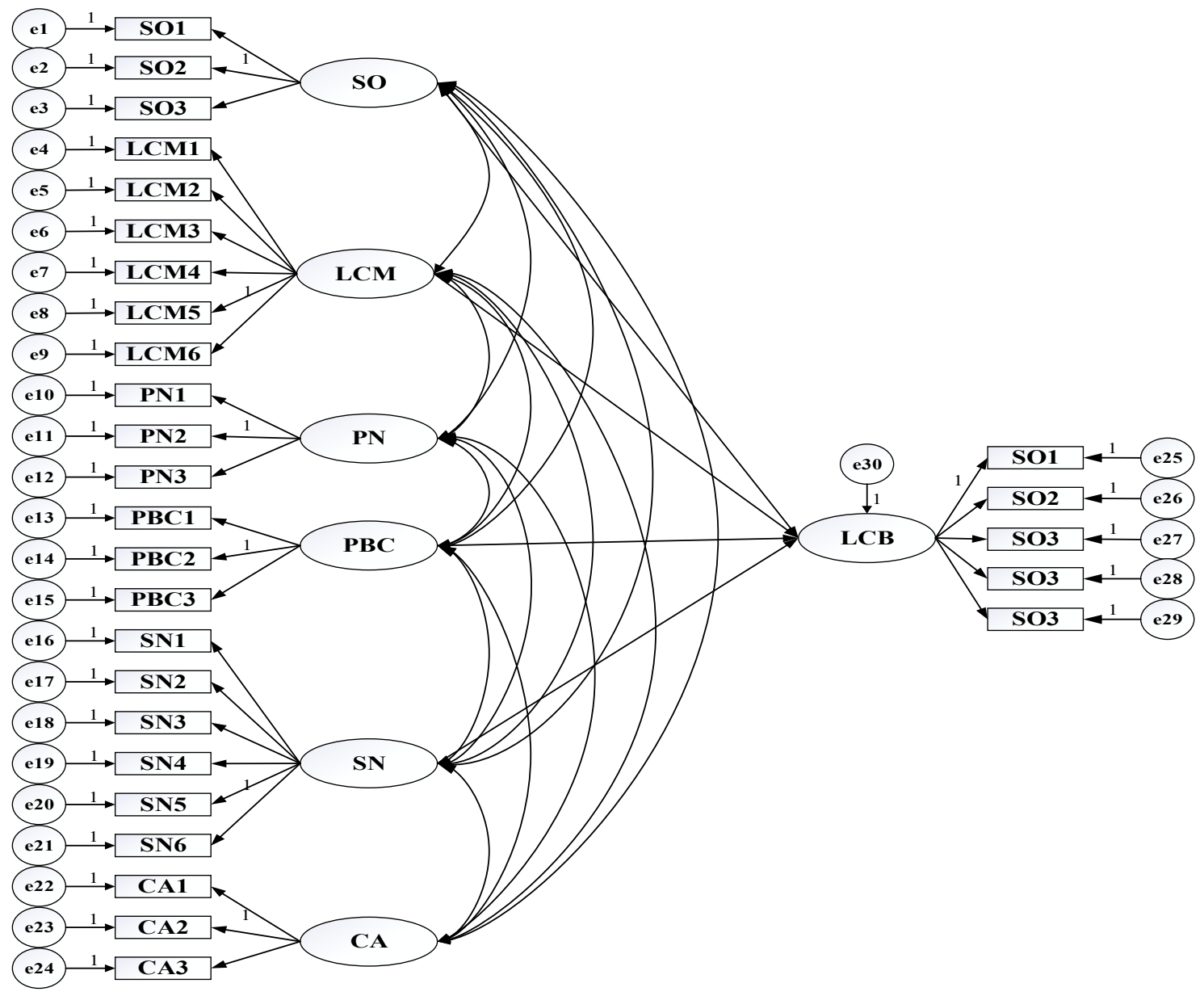

Figure 4. The initial structural model (M1).

As shown in Table 10, there were two insignificant effect paths, i.e., $C A \rightarrow L C B$ and $P N \rightarrow L C B$ $(p>0.05)$ when the initial model was run—suggesting that the factors of customer attitude and personal 
norm exert no direct and significant effects on low-carbon behaviors in star-rated hotels. It can be found in Table 11 that this model was not perfect due to the goodness-of-fit index (GFI) being lower than the allowable limit (0.9). Hence, it is the current model that was necessarily required to be improved for better goodness-of-fit. The model evolved following the modification sequence from model reduction to model expansion in this research. Particularly, the model was modified each time by deleting the least significant path whose $p$-value was the highest in the duration of model reduction. Based on such guidelines, the paths of $\mathrm{CA} \rightarrow \mathrm{LCB}$ and $\mathrm{PN} \rightarrow \mathrm{LCB}$ were eliminated in an orderly fashion $(p>0.05)$, with M2 and M3 obtained in two modification rounds, respectively (Table 12). Still, the model fitness was not yet within a satisfying range after these deletions. Model expansion was then needed for further modification, as no more insignificant paths could be removed.

Table 10. Regression weights in the initial model (M1).

\begin{tabular}{lllcccc}
\hline & Path & & Estimate & SE & $t$-Statistic & $p$-Value \\
\hline SO & $\rightarrow$ & LCB & 0.500 & 0.078 & 6.436 & $* * *$ \\
LCM & $\rightarrow$ & LCB & 0.339 & 0.059 & 5.738 & $* * *$ \\
PN & $\rightarrow$ & LCB & -0.069 & 0.040 & -1.751 & 0.080 \\
PBC & $\rightarrow$ & LCB & 0.149 & 0.041 & 3.670 & $* * *$ \\
SN & $\rightarrow$ & LCB & 0.133 & 0.049 & 2.733 & $* *$ \\
CA & $\rightarrow$ & LCB & -0.071 & 0.049 & -1.453 & 0.146 \\
\hline \multicolumn{7}{c}{ Note: ${ }^{* * *} p<0.001 .{ }^{* *} p<0.01}$.
\end{tabular}

Table 11. Goodness-of-fit of the initial structural model (M1).

\begin{tabular}{cccc}
\hline Goodness-of-Fit Measure & $\begin{array}{c}\text { Level of } \\
\text { Acceptance Fit }\end{array}$ & Fit Statistics \\
\hline \multirow{3}{*}{ Absolute fit } & $\mathrm{X}^{2} / \mathrm{df}$ & $<3.00$ & 2.572 \\
& GFI & $>0.90$ & 0.871 \\
& AGFI & $>0.80$ & 0.843 \\
Incremental fit & RMSEA & $<0.08$ & 0.060 \\
& TLI & $>0.95$ & 0.951 \\
\multirow{2}{*}{ Parsimonious fit } & IFI & $>0.90$ & 0.957 \\
& CFI & $>0.90$ & 0.957 \\
\hline
\end{tabular}

Table 12. Goodness-of-fit in the process of model modification.

\begin{tabular}{|c|c|c|c|c|c|c|c|c|c|c|}
\hline \multirow{2}{*}{\multicolumn{2}{|c|}{ Goodness-of-Fit Measure }} & \multicolumn{8}{|c|}{ Fit Statistics } & \multirow{2}{*}{$\begin{array}{c}\text { Level of } \\
\text { Acceptance Fit }\end{array}$} \\
\hline & & M2 & M3 & M4 & M5 & M6 & M7 & M8 & M9 & \\
\hline \multirow[t]{3}{*}{ Absolute fit } & $\mathrm{X}^{2} / \mathrm{df}$ & 2.555 & 2.572 & 2.340 & 2.242 & 2.178 & 2.124 & 2.074 & 2.030 & $<3.00$ \\
\hline & AGFI & 0.843 & 0.843 & 0.855 & 0.860 & 0.864 & 0.869 & 0.873 & 0.876 & $>0.80$ \\
\hline & RMSEA & 0.060 & 0.060 & 0.055 & 0.053 & 0.052 & 0.051 & 0.049 & 0.048 & $<0.08$ \\
\hline Incremental fit & TLI & 0.952 & 0.951 & 0.958 & 0.962 & 0.963 & 0.965 & 0.967 & 0.968 & $>0.95$ \\
\hline \multirow[t]{2}{*}{ Parsimonious fit } & PNFI & 0.820 & 0.822 & 0.825 & 0.825 & 0.824 & 0.823 & 0.822 & 0.821 & $>0.50$ \\
\hline & PGFI & 0.842 & 0.844 & 0.847 & 0.847 & 0.846 & 0.845 & 0.844 & 0.843 & $>0.50$ \\
\hline
\end{tabular}

To improve scalar invariance, the modification index (MI) was used in this phase of model modification. The parameter with a high value of MI could be freed from constraints and this indicated the improvement of the given correlation [102]. Therefore, the model was thoroughly modified according to the largest MI for correlation improvement, with its practical significance considered. The new correlations were constructed successively as follows: "e18<=>e19" $(\mathrm{MI}=66.049) \rightarrow \mathrm{M} 4$, "e17<=>e18" (MI = 34.907) $\rightarrow \mathrm{M} 5$, "e16<=>e17" $(\mathrm{MI}=23.244) \rightarrow \mathrm{M} 6, " \mathrm{e} 3<=>\mathrm{e} 9 "(\mathrm{MI}=20.802) \rightarrow \mathrm{M} 7$, 
"e28<=>e29" (MI = 17.051) $\rightarrow \mathrm{M} 8$, "e4<=>e6" (MI = 15.903) $\rightarrow$ M9, leading to the final model being perfectly modified. Indices of model fitness in the whole process of model modification are presented in Table 12. The model would not continue to be modified until all the indices met their own standardized minimum thresholds.

\subsubsection{Assessment of the Tested Structural Model}

As shown in Table 12, all the goodness-of-fit indices in the modified model (M9) satisfied their own threshold values, which means that M9 had strong explanatory power and could be thus confirmed as the final model. Standardized estimation coefficients of the final model, as depicted on each path in Figure 5, reflects the weight that construct items contribute to latent variables and the impact of the influencing factors on low-carbon behaviors of staff in star-rated hotels. The standardized weights of different dimensions for construct items are more than $0.700(p<0.001)$, illustrating the fact that all of them significantly affect their corresponding constructs.

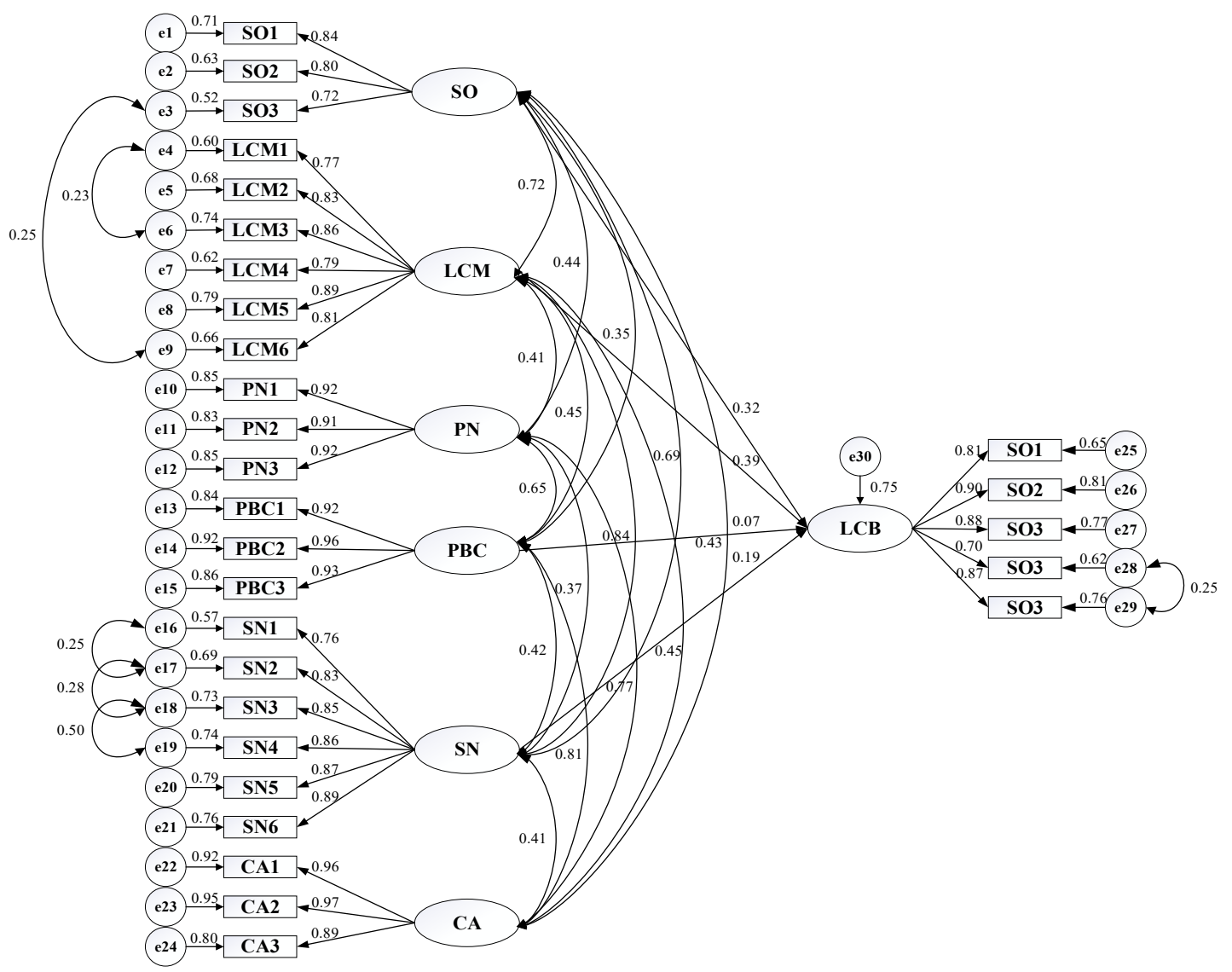

Figure 5. Standardized estimation of the final model (M9).

Th results of all hypothesized paths tested in the final model are presented in Table 13. Both PN and CA insignificantly affect low-carbon behaviors in star-rated hotels, indicating rejections of the original Hypothesis 3 and Hypothesis 6. LCM exerts the most positive 0.393 effect on low-carbon behaviors in star-rated hotels $(p<0.001)$, which supports Hypothesis 2 , followed by SO, SN, and PBC, respectively. SO has a positive 0.322 effect $(p<0.001)$, supporting Hypothesis 1 , and SN has a positive 0.192 effect $(p<0.01)$, supporting Hypothesis 5. By comparison, PBC seems to have the least influence, with a path coefficient of $0.074(p<0.05)$, which supports Hypothesis 4 . The total and partial effects of the factors that influence low-carbon behaviors in star-rated hotels are shown in Table 14. More details of them will be discussed in the next section. 
Table 13. Results of hypothesis test in the final model.

\begin{tabular}{lcccccc}
\hline & Path & & Hypothesis & Coefficient & $t$-Statistic & $p$-Value \\
\hline $\mathrm{SO}$ & $\rightarrow$ & LCB & H1 & 0.322 & 6.102 & $* * *$ \\
LCM & $\rightarrow$ & LCB & H2 & 0.393 & 5.355 & $* * *$ \\
PBC & $\rightarrow$ & LCB & H4 & 0.074 & 2.175 & $*$ \\
SN & $\rightarrow$ & LCB & H5 & 0.192 & 2.996 & $* *$ \\
\hline \multicolumn{5}{c}{ Note: ${ }^{* * *} p<0.001 .{ }^{* *} p<0.01 .{ }^{*} p<0.05}$.
\end{tabular}

Table 14. Effects of factors on low-carbon behavior of staff in hotels (LCB) in the final model.

\begin{tabular}{ccccc}
\hline Effects on LCB & SO & LCM & PBC & SN \\
\hline LCB & 0.322 & 0.393 & 0.074 & 0.192 \\
LCB1 & $(0.259)$ & $(0.316)$ & $(0.059)$ & $(0.155)$ \\
LCB2 & $(0.290)$ & $(0.353)$ & $(0.066)$ & $(0.173)$ \\
LCB3 & $(0.283)$ & $(0.345)$ & $(0.065)$ & $(0.169)$ \\
LCB4 & $(0.253)$ & $(0.309)$ & $(0.058)$ & $(0.151)$ \\
LCB5 & $(0.280)$ & $(0.341)$ & $(0.064)$ & $(0.167)$ \\
\hline
\end{tabular}

Note: Values in the first line indicate the total effects of each influencing factor on LCB. Bracketed values in the following lines indicate the partial effect on each construct item of LCB. PN and CA have no influence on LCB, so they are not shown.

\section{Discussion on Key Factors and Strategy Proposals}

\subsection{Key Factor 1: Low-Carbon Managerial Activities}

The current results underline the priority of low-carbon managerial activities, indicating that low-carbon publicity (LCM5) stands out as the most crucial managerial solution affecting the implementation of staff's low-carbon behaviors in star-rated hotels, whose direct influencing coefficient is the highest at 0.89 . This is consistent with the orientation to low-carbon tourism consumption publicity proposed by Luo and Zhang (2011) [103], but the finding in this research reveal that public service announcements to hotel guests like low-carbon banners, signs, flags or other visuals would also guide the voluntary low-carbon behavior of internal staff by osmosis. Therefore, to ensure the effectivity of low-carbon management in star-rated hotels, soft solutions, such as low-carbon consumption publicity, green training, or organizing frequent voluntary activities designed to advance employees' low-carbon operation experience, are all of necessity as education/learning functions to guide the low-carbon behavior adoption of staff. Simultaneously, as revealed in prior research $[9,104]$, hard solutions cannot be omitted in management processes, e.g., low-carbon technology improvement or facility upgrades and appropriate rewards or penalties for staff from time to time. From the above, Strategy 1 is proposed to facilitate the low-carbon behaviors of staff working for star-rated hotels: put effective low-carbon management into practice and implement multiple managerial activities with both hard and soft approaches.

\subsection{Key Factor 2: Strategic Orientation}

Low-carbon strategic orientation is the second factor strongly affecting staff's low-carbon behaviors in star-rated hotels, with a direct effect coefficient of 0.322. This is consistent with the findings of Bonilla et al. (2011) where the pro-environmental behaviors of most hotels they surveyed were internally driven by the purpose of the strategic decisions made by management [105]. According to the above results, the SO1 item suggests that hotel leadership is an important agent and must make low-carbon strategic orientation its duty, which is a prerequisite for hotel staff to follow the strategic objective of low-carbon hotel development. Moreover, the SO2 item indicates that low-carbon strategic orientation helps star-rated hotels build an eco-culture and a positive brand image to increase the advantages of gains in the market. These important invisible and priceless assets could exert a long-term subtle influence on hotel staff so as to lead them towards voluntarily regulating their own behaviors. Additionally, the SO3 
item implies that it is a valuable approach for low-carbon strategic orientation in hotels by formulating explicit management regulations related to low carbon and energy conservation. Hence, Strategy 2 is then developed: improve the levels of low-carbon behavior by hotel staff, in order to enable a low-carbon strategic orientation that depends on strong leadership, culture/brand and management regulations, and create a benchmark in the lodging industry.

\subsection{Key Factor 3: Social Norms}

Social norm is the only external predictor with a direct significant impact of 0.192 on staff's low-carbon behaviors in star-rated hotels. The findings are in line with the conclusion of Chen and Li (2019) —-that governmental departments or non-governmental organizations should properly encourage and guide individual low-carbon behaviors through laws, policies and social media [84]. Social norms could be regarded as externalizations of personal ethics, showing the concrete reflection and embodiment of individual values in a certain context. There are two means by which to make full use of social norms from the results of this research. The first way is to create an inspired low-carbon atmosphere. In particular, in the mobile internet era, with high public awareness of low carbon and environmental protection, any high-carbon behavior by staff might be exposed, which urges star-rated hotels to consciously shoulder their due social responsibilities in order to avoid negative public opinions from mass media. Moreover, a healthy competitive micro-environment catalyzes low-carbon development in the hotel industry. Domestic star-rated hotels always compete closely with each other for limited market resources; meanwhile, they resist the competition pressure from international hotels, e.g., Marriott, Hilton, Accor, and Shangri-La. Under such conditions, the low-carbon behavior implementation of internal staff could help enhance hotel marketing competitiveness by controlling running costs and increasing the hotel's social reputation. The second way to achieve this is by taking proper advantage of restraint-oriented social norms. This provides strong evidence for the view that governments play a specific, crucially important role [106]. If the government conducts administrative interventions, clarifies the demand for low-carbon principles, and provides the required market policies, low-carbon behavior among staff in the lodging industry will be constrained into a relatively normative pattern. Thus, Strategy 3 is proposed: encourage an inspiration-oriented social atmosphere along with a healthy competitive market environment and guide the timely implementation of restraint-oriented low-carbon policies.

\subsection{Key Factor 4: Perceived Behavior Control}

Perceived behavior control is another key factor affecting staff's low-carbon behaviors in star-rated hotels (with the direct effect of 0.074). The findings that individual time and energy (PBC2) positively affect the low-carbon behaviors in star-rated hotels are in agreement with those proposed by Stone and Fernandez (2008) [107]. Based on this, more low-carbon education programs could be introduced for boosting staff behavior, in which they would be provided with more time and energy for reflection and participation, hence conducting targeted low-carbon behaviors [108-110]. It was previously found that environmental knowledge, reflecting personal literacy, influenced employees' associated attitudes and behaviors [111]. Our findings further support this result that knowledge level (PBC1) is particularly crucial to low-carbon behavior adoption for star-rated hotels. Furthermore, the hypothesis of the positive effect of individual competitiveness (PBC3) on staff's low-carbon behaviors is proven. As for a star-rated hotel that is used to implementing low-carbon practices, hotel managers prefer to select employees with more energy and carbon reduction knowledge than those with less. Therefore, it seems that a high low-carbon knowledge level helps increase the individual competitiveness of employees and the possibility of gaining access to work or even promotion. Moreover, in agreement with the view of Teng et al., (2014) [111], the hotel industry is expected to carry out motivation and incentive programs for energy conservation and carbon reduction in order to make their staff more competitive by applying low-carbon knowledge and developing pro-environmental awareness and behaviors. Therefore, Strategy 4 is accordingly proposed: frequently provide comprehensive education and 
incentive programs for hotel staff at different levels in order to enhance the ability of their perceived behavior control.

\section{Conclusions}

Guiding sustainable development across the lodging industry normally requires the support and involvement of hotel staff, so the implementation of low-carbon behaviors among these staff can make a great difference in helping star-rated hotels become green. Therefore, this research aimed to identify the key influencing factors of staff's low-carbon behaviors in star-rated hotels and their respective impact both inside and outside of the hotel context. First, a set of six influencing factors of low-carbon behavior among staff was identified according to literature retrieval, grounded theory and in-depth interviews, presented as a hypothesized model for triggering low-carbon behavior among staff in star-rated hotels. Structural equation modelling (SEM) was then applied to explore the impact of the identified factors on low-carbon behavior among staff implementation in star-rated hotels. Based on the study findings and discussions provided above, targeted strategies were then proposed.

The results show that three internal factors (i.e., strategic orientation, low-carbon managerial activities, and perceived behavior control) and one single external factor (i.e., social norms) significantly affected hotel staff's low-carbon behaviors. More specifically, the factor of low-carbon managerial activities exerts the most critical influencing factor. However, personal norms and consumer attitude were found to have no statistically significant effect on hotel staff's low-carbon behaviors. Finally, four strategies were discussed in relation to how to facilitate low-carbon practices by staff on the basis of key factor analyses: Strategy 1-put effective low-carbon management into practice and implement multiple managerial activities with both hard and soft approaches; Strategy 2-improve the levels of low-carbon behavior by hotel staff, in order to enable a low-carbon strategic orientation that depends on strong leadership, culture/brand and management regulations, and create a benchmark in the lodging industry; Strategy 3 -encourage an inspiration-oriented social atmosphere along with a healthy competitive market environment and guide the timely implementation of restraint-oriented low-carbon policies; and Strategy 4-frequently provide comprehensive education and incentive programs for hotel staff at different levels in order to enhance the ability of their perceived behavior control.

The findings in this research offer both theoretical implications and practical implications. Generally, prior studies on the influencing factors of low-carbon behavior in the hospitality industry mainly stressed what triggered the low-carbon behavior of hotel guests rather than that of the hotel service side. Some others conducted studies only on individual psychological levels, focusing on psychology-related factors that affected the behavior of either managers or employees in hotels. Hence, this research makes up for the insufficient literature by identifying the influencing factors of hotel staff's low-carbon behaviors both inside and outside of the hotel context. Although the factor of consumer attitude had a negative impact in this research, it could lead to further academic discussions about the relationship between hotel consumers and low-carbon behavior adoption in the hospitality industry. The findings also present several practical implications. Despite legislation tightening low-carbon policies and prioritizing eco-operation in low-carbon industries, a comprehensive system of policies and norms regarding low-carbon development is still lacking in the lodging sector nationwide. Hence, the current research is conducive to improving relevant policies and norms and for the authorities to close the gap between low-carbon hotel practice and policymaking. Furthermore, the proposed strategies provide a reference for hoteliers and the government on how to guide the effective implementation of low-carbon behaviors among hotel staff, which not only helps to create a low-carbon competitive hospitality market, but also contributes to conveying pro-environmental attributes to the whole of society. Although this is an empirical study of Eastern China, the research findings could be used in other regions or countries.

The research aim has been successfully achieved, though there are still some limitations. The present research was limited to different star-rated hotels for homogeneity, while future work will focus on the differences among hotels with different stars. Moreover, this empirical survey was restrictedly conducted in 
typical star-rated hotels in Eastern China. Larger samples from other, different areas will be collected and theoretical models will be optimized for confirmatory factor analysis in further research. Meanwhile, hotel differences caused by whether or not they belong to a hotel chain will be also considered in the future in order to explore the influence of chain management pressure on the low-carbon behaviors of staff.

Author Contributions: Conceptualization, J.L. and P.M.; data curation, J.W.; formal analysis, J.L.; investigation, H.L. (Hui Liu) and J.W.; methodology, P.M.; resources, P.M.; supervision, H.L. (Hongyang Li) and J.Y.; writing—original draft, J.L.; writing-review and editing, J.L., P.M., H.L. (Hui Liu) and H.L. (Hongyang Li); funding acquisition, P.M. and J.Y. All authors have read and agreed to the published version of the manuscript.

Funding: This research was funded by the National Natural Science Foundation of China, grant numbers 72071115 and 71671042, the National Social Science Foundation of China, grant number 19CGL065, the Fundamental Research Funds for the Central Universities, the "13th Five-Year" Plan of Philosophy and Social Sciences of Guangdong Province (2019 General Project), project number GD19CGL27, the State Key Laboratory of Subtropical Building Science, South China University of Technology, China (2020ZB17).

Conflicts of Interest: The authors declare no conflict of interest.

\section{References}

1. Gössling, S.; Peeters, P. Assessing tourism's global environmental impact 1900-2050. J. Sustain. Tour. 2015, 23, 639-659. [CrossRef]

2. Merli, R.; Preziosi, M.; Acampora, A.; Ali, F. Why should hotels go green? Insights from guests experience in green hotels. Int. J. Hosp. Manag. 2019, 81, 169-179. [CrossRef]

3. Michopoulos, A.; Ziogou, I.; Kerimis, M.; Zachariadis, T. A study on hot-water production of hotels in Cyprus: Energy and environmental considerations. Energy Build. 2017, 150, 1-12. [CrossRef]

4. Han, H.; Lee, J.-S.; Trang, H.L.T.; Kim, W. Water conservation and waste reduction management for increasing guest loyalty and green hotel practices. Int. J. Hosp. Manag. 2018, 75, 58-66. [CrossRef]

5. Xing, J.; Ren, P.; Ling, J. Analysis of energy efficiency retrofit scheme for hotel buildings using eQuest software: A case study from Tianjin, China. Energy Build. 2015, 87, 14-24. [CrossRef]

6. Huang, K.-T.; Wang, J.C.; Wang, Y.-C. Analysis and benchmarking of greenhouse gas emissions of luxury hotels. Int. J. Hosp. Manag. 2015, 51, 56-66. [CrossRef]

7. Pinto, A.; Afonso, A.S.; Santos, A.S.; Pimentel-Rodrigues, C.; Rodrigues, F. Nexus water energy for hotel sector efficiency. Energy Procedia 2017, 111, 215-225. [CrossRef]

8. Petrevska, B.; Cingoski, V. Can Macedonian Hotels Be Green: The Evidence of Hotel "Flamingo"—Gevgelija, Macedonia. Mech. Eng. Sci. J. Proc. 2016, 34, 311-321.

9. Mardani, A.; Zavadskas, E.K.; Streimikiene, D.; Jusoh, A.; Nor, K.M.; Khoshnoudi, M. Using fuzzy multiple criteria decision making approaches for evaluating energy saving technologies and solutions in five star hotels: A new hierarchical framework. Energy 2016, 117, 131-148. [CrossRef]

10. Pham, N.T.; Tučková, Z.; Jabbour, C.J.C. Greening the hospitality industry: How do green human resource management practices influence organizational citizenship behavior in hotels? A mixed-methods study. Tour. Manag. 2019, 72, 386-399. [CrossRef]

11. Yuan, J.; Xu, Y.; Hu, Z.; Zhao, C.; Xiong, M.; Guo, J. Peak energy consumption and CO2 emissions in China. Energy Policy 2014, 68, 508-523. [CrossRef]

12. Fatoki, O. Hotel Employees' Pro-Environmental Behaviour: Effect of Leadership Behaviour, Institutional Support and Workplace Spirituality. Sustainability 2019, 11, 4135. [CrossRef]

13. Paillé, P.; Morelos, J.H.M.; Raineri, N.; Stinglhamber, F. The influence of the immediate manager on the avoidance of non-green behaviors in the workplace: A three-wave moderated-mediation model. J. Bus. Ethics. 2019, 155, 723-740. [CrossRef]

14. Teng, C.C.; Lu, A.C.C.; Huang, T.T. Drivers of consumers' behavioral intention toward green hotels. Int. J. Contemp. Hosp. Manag. 2018, 30, 1134-1151. [CrossRef]

15. Chou, C. Hotels' environmental policies and employee personal environmental beliefs: Interactions and outcomes. Tour. Manag. 2014, 40, 436-446. [CrossRef]

16. Chan, E.S.; Hon, A.H.; Okumus, F.; Chan, W.W. An Empirical Study of Environmental Practices and Employee Ecological Behavior in the Hotel Industry. J. Hosp. Tour. Res. 2017, 41, 585-608. [CrossRef] 
17. Wang, L.; Wong, P.P.W.; Alagas, E.N. Antecedents of green purchase behavior: An examination of altruism and environmental knowledge. Int. J. Cult. Tour. Hosp. Res. 2020, 14, 63-82. [CrossRef]

18. Karatepe, O.M.; Rezapouraghdam, H.; Hassannia, R. Job insecurity, work engagement and their effects on hotel employees' non-green and nonattendance behaviors. Int. J. Hosp. Manag. 2020, 87, 102472. [CrossRef]

19. Stern, P.C. New environmental theories: Toward a coherent theory of environmentally significant behavior. J. Soc. Issues 2000, 56, 407-424. [CrossRef]

20. Smitt, S.; Tolstorebrov, I.; Hafner, A. Integrated CO2 system with HVAC and hot water for hotels: Field measurements and performance evaluation. Int. J. Refrig. 2020, 116, 59-69. [CrossRef]

21. Dhirasasna, N.; Becken, S.; Sahin, O. A systems approach to examining the drivers and barriers of renewable energy technology adoption in the hotel sector in Queensland, Australia. J. Hosp. Tour. Manag. 2020, 42, 153-172. [CrossRef]

22. Becchio, C.; Corgnati, S.P.; Vio, M.; Crespi, G.; Prendin, L.; Magagnini, M. HVAC solutions for energy retrofitted hotel in Mediterranean area. Energy Procedia 2017, 133, 145-157. [CrossRef]

23. Dharmesti, M.; Merrilees, B.; Winata, L. "I'm mindfully green": Examining the determinants of guest pro-environmental behaviors (PEB) in hotels. J. Hosp. Mark. Manag. 2020. [CrossRef]

24. Budovska, V.; Torres Delgado, A.; Øgaard, T. Pro-environmental behaviour of hotel guests: Application of the Theory of Planned Behaviour and social norms to towel reuse. Tour. Hosp. Res. 2020, 20, 105-116. [CrossRef]

25. Yarimoglu, E.; Gunay, T. The extended theory of planned behavior in Turkish customers' intentions to visit green hotels. Bus. Strateg. Environ. 2019, 29, 1097-1108. [CrossRef]

26. Chuah, S.H.W.; El-Manstrly, D.; Tseng, M.L.; Ramayah, T. Sustaining customer engagement behavior through corporate social responsibility: The roles of environmental concern and green trust. J. Clean. Prod. 2020, 262, 121348. [CrossRef]

27. Della Volpi, Y.; Paulino, S.R. The Sustainability of Services: Considerations on the materiality of accommodation services from the concept of life cycle thinking. J. Clean. Prod. 2018, 192, 327-334. [CrossRef]

28. Mar Alonso-Almeida, M.; Rodríguez-Antón, J.M. Organisational behaviour and strategies in the adoption of certified management systems: An analysis of the Spanish hotel industry. J. Clean. Prod. 2011, 19, 1455-1463. [CrossRef]

29. Linneberg, M.S.; Madsen, M.T.; Nielsen, J.A. Micro-level translation of corporate sustainability: When strategy meets practice in the Danish hospitality sector. J. Clean. Prod. 2019, 240, 118159. [CrossRef]

30. Ahn, Y.H.; Pearce, A.R. Green luxury: A case study of two green hotels. J. Green Build. 2013, 8, 90-119. [CrossRef]

31. Hsu, C.W.; Kuo, T.C.; Shyu, G.S.; Chen, P.S. Low carbon supplier selection in the hotel industry. Sustainability 2014, 6, 2658-2684. [CrossRef]

32. Liu, X.; Pan, Y. A study of carbon emissions during a tour: A case study of a four-day guided tour in Guilin, China. J. Hosp. Tour. Manag. 2016, 29, 80-87. [CrossRef]

33. De Grosbois, D. Corporate social responsibility reporting by the global hotel industry: Commitment, initiatives and performance. Int. J. Hosp. Manag. 2012, 31, 896-905. [CrossRef]

34. Verma, V.K.; Chandra, B. An application of theory of planned behavior to predict young Indian consumers' green hotel visit intention. J. Clean. Prod. 2018, 172, 1152-1162. [CrossRef]

35. Gössling, S.; Araña, J.E.; Aguiar-Quintana, J.T. Towel reuse in hotels: Importance of normative appeal designs. Tour. Manag. 2019, 70, 273-283. [CrossRef]

36. Alipour, H.; Safaeimanesh, F.; Soosan, A. Investigating Sustainable Practices in Hotel Industry-from Employees' Perspective: Evidence from a Mediterranean Island. Sustainability 2019, 11, 6556. [CrossRef]

37. Assaker, G.; O'Connor, P.; El-Haddad, R. Examining an integrated model of green image, perceived quality, satisfaction, trust, and loyalty in upscale hotels. J. Hosp. Mark. Manag. 2020. [CrossRef]

38. Preziosi, M.; Tourais, P.; Acampora, A. The role of environmental practices and communication on guest loyalty: Examining EU-Ecolabel in Portuguese hotels. J. Clean. Prod. 2019, 237, 117659. [CrossRef]

39. Molina-Azorín, J.F.; Tarí, J.J.; Pereira-Moliner, J.; Lopez-Gamero, M.D.; Pertusa-Ortega, E.M. The effects of quality and environmental Management on competitive advantage: A mixed methods study in the hotel industry. Tour. Manag. 2015, 50, 41-54. [CrossRef]

40. Wong, A.K.F.; Kim, S.S. Development and validation of standard hotel corporate social responsibility (CSR) scale from the employee perspective. Int. J. Hosp. Manag. 2020, 87, 102507. [CrossRef]

41. Dube, K.; Nhamo, G. Greenhouse Gas Emissions and Sustainability in Victoria Falls: Focus on Hotels, Tour Operators and Related Attractions. Afr. Geogr. Rev. 2020. [CrossRef] 
42. Salehi, M.; Filimonau, V.; Asadzadeh, M.; Ghaderi, E. Strategies to improve energy and carbon efficiency of luxury hotels in Iran. Sustain. Prod. Consum. 2020, 26, 1-15. [CrossRef]

43. Hoekman, J.; Frenken, K.; Tijssen, R.J. Research collaboration at a distance: Changing spatial patterns of scientific collaboration within Europe. Res. Policy 2010, 39, 662-673. [CrossRef]

44. Mongeon, P.; Paul-Hus, A. The journal coverage of Web of Science and Scopus: A comparative analysis. Scientometrics 2016, 106, 213-228. [CrossRef]

45. Tam, W.V.; Le, K.N.; Tran, C.N.N.; Wang, J.Y. A review on contemporary computational programs for Building's life-cycle energy consumption and greenhouse-gas emissions assessment: An empirical study in Australia. J. Clean. Prod. 2018, 172, 4220-4230. [CrossRef]

46. Gao, L.; Wang, S.; Li, J.; Li, H. Application of the extended theory of planned behavior to understand individual's energy saving behavior in workplaces. Resour. Conserv. Recycl. 2017, 127, 107-113. [CrossRef]

47. Kucukusta, D.; Mak, A.; Chan, X. Corporate social responsibility practices in four and five-star hotels: Perspectives from Hong Kong visitors. Int. J. Hosp. Manag. 2013, 34, 19-30. [CrossRef]

48. Coles, T.; Fenclova, E.; Dinan, C. Tourism and corporate social responsibility: A critical review and research agenda. Tour. Manag. Perspect. 2013, 6, 122-141. [CrossRef]

49. Joshi, Y.; Rahman, Z. Factors affecting green purchase behaviour and future research directions. Int. Strat. Manag. Rev. 2015, 3, 128-143. [CrossRef]

50. Newell, B.R.; McDonald, R.I.; Brewer, M.; Hayes, B.K. The psychology of environmental decisions. Annu. Rev. Environ. Resour. 2014, 39, 443-467. [CrossRef]

51. Granovetter, M. Economic action and social structure: The problem of embeddedness. Am. J. Sociol. 1985, 91, 481-510. [CrossRef]

52. McGinley, S.; O'Neill, J.; Damaske, S.; Mattila, A.S. A grounded theory approach to developing a career change model in hospitality. Int. J. Hosp. Manag. 2014, 38, 89-98. [CrossRef]

53. Zou, P.X.; Wagle, D.; Alam, M. Strategies for minimizing building energy performance gaps between the design intend and the reality. Energy Build. 2019, 191,31-41. [CrossRef]

54. Luo, X.; Bhattacharya, C.B. Corporate social responsibility, customer satisfaction, and market value. J. Mark. 2006, 70, 1-18. [CrossRef]

55. Chaney, D.; Carrillat, F.A.; Zouari, A. Uncovering institutional orientation as a new strategic orientation in industrial marketing. Ind. Mark. Manag. 2019, 80, 242-250. [CrossRef]

56. Voss, G.B.; Voss, Z.G. Strategic orientation and firm performance in an artistic environment. J. Mark. 2000, 64, 67-83. [CrossRef]

57. Teixeira, A.; Ferreira, M.R.; Correia, A.; Lima, V. Students' perceptions of corporate social responsibility: Evidences from a Portuguese higher education institution. Int. Rev. Public Nonprofit Mark. 2018, 15, $235-252$. [CrossRef]

58. Park, J.; Jeong Kim, H.; McCleary, K.W. The impact of top Management's environmental attitudes on hotel companies' environmental Management. J. Hosp. Tour. Res. 2014, 38, 95-115. [CrossRef]

59. Buffa, F.; Franch, M.; Rizio, D. Environmental Management practices for sustainable business models in small and medium sized hotel enterprises. J. Clean. Prod. 2018, 194, 656-664. [CrossRef]

60. Reid, S.; Johnston, N.; Patiar, A. Coastal resorts setting the pace: An evaluation of sustainable hotel practices. J. Hosp. Tour. Manag. 2017, 33, 11-22. [CrossRef]

61. Fornara, F.; Pattitoni, P.; Mura, M.; Strazzera, E. Predicting intention to improve household energy efficiency: The role of value-belief-norm theory, normative and informational influence, and specific attitude. J. Environ. Psychol. 2016, 45, 1-10. [CrossRef]

62. Harland, P.; Staats, H.; Wilke, H.A. Situational and personality factors as direct or personal norm mediated predictors of pro-environmental behavior: Questions derived from norm-activation theory. Basic Appl. Soc. Psychol. 2007, 29, 323-334. [CrossRef]

63. Holdsworth, S.; Sandri, O.; Thomas, I.; Wong, P.; Chester, A.; McLaughlin, P. The assessment of graduate sustainability attributes in the workplace: Potential advantages of using the theory of planned behaviour (TPB). J. Clean. Prod. 2019, 238, 117929. [CrossRef]

64. Ru, X.; Wang, S.; Yan, S. Exploring the effects of normative factors and perceived behavioral control on individual's energy-saving intention: An empirical study in eastern China. Resour. Conserv. Recycl. 2018, 134, 91-99. [CrossRef] 
65. Kollmuss, A.; Agyeman, J. Mind the gap: Why do people act environmentally and what are the barriers to pro-environmental behavior? Environ. Educ. Res. 2002, 8, 239-260. [CrossRef]

66. Donald, I.J.; Cooper, S.R.; Conchie, S.M. An extended theory of planned behavior model of the psychological factors affecting commuters' transport mode use. J. Environ. Psychol. 2014, 40, 39-48. [CrossRef]

67. Cai, S.; Long, X.; Li, L.; Liang, H.; Wang, Q.; Ding, X. Determinants of intention and behavior of low carbon commuting through bicycle-sharing in China. J. Clean. Prod. 2019, 212, 602-609. [CrossRef]

68. Farrow, K.; Grolleau, G.; Ibanez, L. Social norms and pro-environmental behavior: A review of the evidence. Ecol. Econ. 2017, 140, 1-13. [CrossRef]

69. Reynolds, K.J.; Subašić, E.; Tindall, K. The problem of behaviour change: From social norms to an ingroup focus. Soc. Personal. Psychol. Compass 2015, 9, 45-56. [CrossRef]

70. Pickett-Baker, J.; Ozaki, R. Pro-environmental products: Marketing influence on consumer purchase decision. J. Consum. Mark. 2008, 25, 281-293. [CrossRef]

71. Nolan, J.M.; Schultz, P.W.; Cialdini, R.B.; Goldstein, N.J.; Griskevicius, V. Normative social influence is underdetected. Personal. Soc. Psychol. Bull. 2008, 34, 913-923. [CrossRef]

72. Bamberg, S.; Hunecke, M.; Blöbaum, A. Social context, personal norms and the use of public transportation: Two field studies. J. Environ. Psychol. 2007, 27, 190-203. [CrossRef]

73. Ajzen, I. The theory of planned behavior. Organ. Behav. Hum. Dec. Process. 1991, 50, 179-211. [CrossRef]

74. Yap, S.F.; Kew, M.L. Service quality and customer satisfaction: Antecedents of customer's re-patronage intentions. Sunway Acad. J. 2007, 4, 59-73.

75. Hsiao, T.-Y.; Chuang, C.-M.; Kuo, N.-W.; Yu, S.M.-F. Establishing attributes of an environmental Management system for green hotel evaluation. Int. J. Hosp. Manag. 2014, 36, 197-208. [CrossRef]

76. Xu, X.; Gursoy, D. Influence of sustainable hospitality supply chain Management on customers' attitudes and behaviors. Int. J. Hosp. Manag. 2015, 49, 105-116. [CrossRef]

77. Yi, S.; Li, X.; Jai, T.M. Hotel guests' perception of best green practices: A content analysis of online reviews. Tour. Hosp. Res. 2018, 18, 191-202. [CrossRef]

78. Pan, L. Study on hotel Management model from the perspective of low carbon tourism. Int. J. Chem. Pharm. Res. 2014, 6, 864-868.

79. Mensah, I. Different shades of green: Environmental Management in hotels in Accra. Int. J. Tour. Res. 2014, 16, 450-461. [CrossRef]

80. Kim, Y.J.; Kim, W.G.; Choi, H.M.; Phetvaroon, K. The effect of green human resource Management on hotel employees' eco-friendly behavior and environmental performance. Int. J. Hosp. Manag. 2019, 76, 83-93. [CrossRef]

81. Peng, X.; Lee, S. Self-discipline or self-interest? The antecedents of hotel employees' pro-environmental behaviours. J. Sustain. Tour. 2019, 27, 1457-1476. [CrossRef]

82. Zhang, J.; Huang, R. Employees' pro-environmental behaviours (PEBs) at international hotel chains (IHCs) in China: The mediating role of environmental concerns (ECs). Int. J. Hosp. Manag. 2019, 39, 129-136. [CrossRef]

83. Li, J.; Tam, V.W.; Zuo, J.; Zhu, J. Designers' attitude and behaviour towards construction waste minimization by design: A study in Shenzhen, China. Resour. Conserv. Recycl. 2015, 105, 29-35. [CrossRef]

84. Chen, W.; Li, J. Who are the low-carbon activists? Analysis of the influence mechanism and group characteristics of low-carbon behavior in Tianjin, China. Sci. Total Environ. 2019, 683, 729-736. [CrossRef]

85. Musavengane, R. Small hotels and responsible tourism practice: Hoteliers' perspectives. J. Clean. Prod. 2019, 220, 786-799. [CrossRef]

86. doPaço, A.; Shiel, C.; Alves, H. A new model for testing green consumer behavior. J. Clean. Prod. 2019, 207, 998-1006.

87. Laguir, I.; Staglianò, R.; Elbaz, J. Does corporate social responsibility affect corporate tax aggressiveness? J. Clean. Prod. 2015, 107, 662-675. [CrossRef]

88. Suki, N.M.; Suki, N.M. Examination of peer influence as a moderator and predictor in explaining green purchase behaviour in a developing country. J. Clean. Prod. 2019, 228, 833-844. [CrossRef]

89. Taufique, K.M.R.; Vaithianathan, S. A fresh look at understanding Green consumer behavior among young urban Indian consumers through the lens of Theory of Planned Behavior. J. Clean. Prod. 2018, 183, 46-55. [CrossRef]

90. Nusair, K.; Hua, N. Comparative assessment of structural equation modeling and multiple regression research methodologies: E-commerce context. Tour. Manag. 2010, 31, 314-324. [CrossRef] 
91. Curran, P.J.; West, S.G.; Finch, J.F. The robustness of test statistics to nonnormality and specification error in confirmatory factor analysis. Psychol. Methods 1996, 1, 16-29. [CrossRef]

92. Kline, R.B. Principles and Practice of Structural Equation Modeling; Guilford Publications: New York, NY, USA, 2015; pp. 66-67.

93. Aigbavboa, C.; Thwala, W. Confirmatory Factor Analysis of Neighbourhood Features amongst South African Low-income Housing Occupants. In Proceedings of the International Conference on Construction and Real Estate Management: Construction and Operation in the Context of Sustainability, Karlsruhe, Germany, 10-11 October 2013; pp. 1107-1122.

94. Hamari, J.; Koivisto, J. Measuring flow in gamification: Dispositional flow scale-2. Comput. Hum. Behav. 2014, 40, 133-143. [CrossRef]

95. Xue, X.; Zhang, X.; Wang, L.; Skitmore, M.; Wang, Q. Analyzing collaborative relationships among industrialized construction technology innovation organizations: A combined SNA and SEM approach. J. Clean. Prod. 2018, 173, 265-277. [CrossRef]

96. Leung, M.Y.; Chan, H.K. Antecedents of commitment in construction Management. Constr. Manag. Econ. 2007, 25, 113-127. [CrossRef]

97. Qureshi, S.M.; Kang, C. Analysing the organizational factors of project complexity using structural equation modelling. Int. J. Proj. Manag. 2015, 33, 165-176. [CrossRef]

98. Hulland, J. Use of partial least squares (PLS) in strategic Management research: A review of four recent studies. Strat. Manag. J. 1999, 20, 195-204. [CrossRef]

99. Lai, W.T.; Chen, C.F. Behavioral intentions of public transit passengers-The roles of service quality, perceived value, satisfaction and involvement. Transp. Policy 2011, 18, 318-325. [CrossRef]

100. Xiong, B.; Skitmore, M.; Xia, B. A critical review of structural equation modeling applications in construction research. Autom. Constr. 2015, 49, 59-70. [CrossRef]

101. Wen Lim, H.; Li, N.; Fang, D.; Wu, C. Impact of Safety Climate on Types of Safety Motivation and Performance: Multigroup Invariance Analysis. J. Manag. Eng. 2018, 34, 04018002. [CrossRef]

102. Ellis, B.B. Differential item functioning: Implications for test translations. J. Appl. Psychol. 1989, 74, 912. [CrossRef]

103. Luo, J.; Zhang, M. Route Choice of low-carbon industry for global climate change: An issue of China tourism reform. Energy Procedia 2011, 5, 2283-2288. [CrossRef]

104. Chan, W. Energy benchmarking in support of low carbon hotels: Developments, challenges, and approaches in China. Int. J. Hosp. Manag. 2012, 31, 1130-1142. [CrossRef]

105. Bonilla Priego, M.J.; Najera, J.J.; Font, X. Environmental Management decision-making in certified hotels. J. Sustain. Tour. 2011, 19, 361-381. [CrossRef]

106. Tsai, K.T.; Lin, T.P.; Hwang, R.L.; Huang, Y.J. Carbon dioxide emissions generated by energy consumption of hotels and homestay facilities in Taiwan. Tour. Manag. 2014, 42, 13-21. [CrossRef]

107. Stone, J.; Fernandez, N.C. To practice what we preach: The use of hypocrisy and cognitive dissonance to motivate behavior change. Soc. Personal. Psychol. Compass 2008, 2, 1024-1051. [CrossRef]

108. DeWaters, J.E.; Powers, S.E. Energy literacy of secondary students in New York State (USA): A measure of knowledge, affect, and behavior. Energy Policy 2011, 39, 1699-1710. [CrossRef]

109. Abdul-Wahab, S.A. A preliminary investigation into the environmental awareness of the Omani public and their willingness to protect the environment. Am. J. Environ. Sci. 2008, 4, 39-49.

110. Tuncer, G.; Tekkaya, C.; Sungur, S.; Cakiroglu, J.; Ertepinar, H.; Kaplowitz, M. Assessing pre-service teachers' environmental literacy in Turkey as a mean to develop teacher education programs. Int. J. Educ. Dev. 2009, 29, 426-436. [CrossRef]

111. Teng, C.C.; Horng, J.S.; Hu, M.L.M.; Chen, P.C. Exploring the energy and carbon literacy structure for hospitality and tourism practitioners: Evidence from hotel employees in Taiwan. Asia Pac. J. Tour. Res. 2014, 19, 451-468. [CrossRef]

Publisher's Note: MDPI stays neutral with regard to jurisdictional claims in published maps and institutional affiliations. 